Article

\title{
Carbon Footprint Comparative Analysis of Cardboard and Plastic Containers Used for the International Transport of Spanish Tomatoes
}

\author{
Vanesa G. Lo-Iacono-Ferreira ${ }^{1, *} * \mathbb{D}$, Rosario Viñoles-Cebolla ${ }^{2}$, María José Bastante-Ceca ${ }^{2} \mathbb{D}$ and \\ Salvador F. Capuz-Rizo ${ }^{2, *} *$ \\ 1 Project Management, Innovation and Sustainability (PRINS) Research Centre, Campus de Alcoy, \\ Universitat Politècnica de València, Plaza Ferrándiz y Carbonell 1, 03801 Alcoy, Spain \\ 2 Project Management, Innovation and Sustainability (PRINS) Research Centre, Campus de Valencia, \\ Universitat Politècnica de València, Camino de Vera s/n, 46022 Valencia, Spain; \\ rovice@dpi.upv.es (R.V.-C.); mabasce1@dpi.upv.es (M.J.B.-C.) \\ * Correspondence: valoia@upv.es (V.G.L.-I.-F.); scapuz@dpi.upv.es (S.F.C.-R.)
}

\section{check for} updates

Citation: Lo-Iacono-Ferreira, V.G.; Viñoles-Cebolla, R.; Bastante-Ceca, M.J.; Capuz-Rizo, S.F. Carbon Footprint Comparative Analysis of Cardboard and Plastic Containers Used for the International Transport of Spanish Tomatoes. Sustainability 2021, 13, 2552. https://doi.org/ $10.3390 /$ su13052552

Academic Editor: Sara González García

Received: 10 December 2020 Accepted: 19 February 2021 Published: 26 February 2021

Publisher's Note: MDPI stays neutral with regard to jurisdictional claims in published maps and institutional affiliations.

Copyright: (c) 2021 by the authors. Licensee MDPI, Basel, Switzerland. This article is an open access article distributed under the terms and conditions of the Creative Commons Attribution (CC BY) license (https:// creativecommons.org/licenses/by/ $4.0 /)$.

\begin{abstract}
Agricultural packaging has a direct impact on the environmental performance of food The carbon footprint (CF) of two of the most used packaging systems for international transport by road of fruit and vegetables is assessed and compared. Corrugated cardboard boxes (CCB) and polypropylene foldable boxes (PPB) in two different sizes are the object of this study. For the reusable boxes, three different scenarios are considered regarding the number of uses of each box $(20,50$, and 100 uses). Product CF ISO 14067:2018 standard is applied, and requirements of ISO 14026:2017 and ISO 14044:2006 are met for a cradle-to-grave CF analysis. Product distribution and return of the empty box are the stages with the most significant impact for PPB over the manufacturing stage. CCB that does not have any returning stage or requirements of sanitation has its main impact in manufacturing. The comparison between both packaging systems of the same size, considering the functional unit and defined scope, points out CCB has a lower CF than PPB.
\end{abstract}

Keywords: greenhouse emissions; fruit and vegetable transport; fruit and vegetable packaging; cardboard boxes; polypropylene boxes

\section{Introduction}

The agriculture sector plays an important role in the economies of countries. It has historically been the foundation of social and economic progress in developed countries [1].

Food is a basic human need, and in order to be satisfied, a complex and increasingly globalized system of production and delivery has developed over time to meet our need for food and different flavors, in a way that some vegetables grown in Spain could be found in markets in the rest of Europe within days [2].

The agricultural sector is critical to social and economic progress, particularly with regard to the eradication of hunger and poverty, the creation of employment and livelihoodearning opportunities, and the generation of trade and foreign exchange earnings [1].

Fruits and vegetables have always been present in the human diet due to their nutritional content. Fruit production has been increasing over the years, following the growth of the world population. The largest worldwide production of fruits consists of bananas (100 million tons), watermelons (99 million tons), apples (71 million tons), and grapes (68 million tons). On the other hand, fresh vegetables (249 million tons) and tomatoes (154 million tons) are the most produced vegetables in the world [3].

However, agriculture is also the source of many environmental problems, among which the overuse of fertilizers, the pollution of waters, the depletion of aquifers, greenhouse gas (GHG) emissions, and increasingly severe periods of droughts can be found [1] 
Sustainable agriculture has as its main objective the reduction of the environmental impact associated with its production processes, facing the main challenges of the current agriculture sector related to water scarcity and GHG emissions [2,3].

\subsection{Transport and Packaging}

Since the main function of packaging is to contain and protect the product during the operations of storage, transport, and distribution, the correct choice of packaging system can be relevant in order to assure the final quality of the product at the destination market. This is especially relevant in the case of transport of perishable products (such as fruit and vegetables), or when the distance of transportation is considerable, as occurs in the case of international transport [4].

Because of the process of the globalization of economies and the development of production techniques, crop yields have been increased and, subsequently, the levels of exportation. Therefore, one of the main sources of GHG associated with the agriculture supply chain comes from the distribution of fruit and vegetables. In these cases, the choice of appropriate packaging, which leads to a lesser greenhouse emission during its complete life cycle, results in great importance $[5,6]$.

In recent years, the scientific community has paid much attention to the relationship between agricultural packaging and its environmental performance; many studies and papers published in the last 20 years about this topic show this. Among them, the studies by Ecobilan (2000) [4], Sauer et al. (2004) [7], Capuz et al. (2005) [8], Singh et al. (2006) [9], Barthel et al. (2007) [10], Albrecht et al. (2009) [11], Levi et al. (2011) [12], Albrecht et al. (2013) [13], Franklin Associates (2016) [14], Bala and Fullana (2017) [15], Pauer et al. (2019) [16], and Lo-Iacono et al. (2020) [17] were selected. Specifically, United Nations Environment Programme (UNEP) presented in 2013 a report including some of the aspects to take into consideration when performing a life cycle assessment (LCA) of these types of packaging [18]. Table 1 gathers these references and extracts the goal and geographic scope of each one to understand its relevance to this study.

Table 1. Goal of studies considered state of the art for transport and packaging.

\begin{tabular}{|c|c|c|c|c|c|}
\hline Year & $\begin{array}{l}\text { Author and } \\
\text { Reference }\end{array}$ & Goal of the Study & Geographic Scope & Containers Considered & $\begin{array}{l}\text { Products } \\
\text { Transported }\end{array}$ \\
\hline 2000 & $\begin{array}{l}\text { Ecobilan } \\
(2000)[4]\end{array}$ & $\begin{array}{l}\text { Comparative analysis of three different } \\
\text { types of packaging for apples. }\end{array}$ & $\begin{array}{l}\text { Distribution within } \\
\text { the French } \\
\text { national market }\end{array}$ & $\begin{array}{l}\text { Wooden boxes } \\
\text { Foldable plastic crates } \\
\text { (Polypropylene, PP) } \\
\text { Cardboard boxes }\end{array}$ & Apples \\
\hline 2004 & $\begin{array}{l}\text { Sauer et al. } \\
(2004)[7]\end{array}$ & $\begin{array}{l}\text { Comparison of plastic containers and } \\
\text { display-ready corrugated containers for } \\
\text { fresh products. }\end{array}$ & $\begin{array}{l}\text { Distribution within } \\
\text { the national } \\
\text { US market }\end{array}$ & $\begin{array}{l}\text { Non-foldable plastic } \\
\text { boxes (PP) } \\
\text { Cardboard boxes }\end{array}$ & $\begin{array}{l}\text { Ten different } \\
\text { fresh fruits and } \\
\text { vegetables }\end{array}$ \\
\hline 2005 & $\begin{array}{l}\text { Capuz et al. } \\
\text { (2005) [8] }\end{array}$ & $\begin{array}{l}\text { Comparative study of the environmental } \\
\text { and economic characteristics of } \\
\text { corrugated cardboard boxes and reusable } \\
\text { plastic crates in the long-distance } \\
\text { transport of fruit and vegetables. }\end{array}$ & $\begin{array}{l}\text { International } \\
\text { distribution (from } \\
\text { Spain to Germany) }\end{array}$ & $\begin{array}{l}\text { Foldable plastic boxes } \\
\text { (High Density } \\
\text { Polyethylene, HDPE) } \\
\text { Cardboard boxes }\end{array}$ & Tomatoes \\
\hline 2006 & $\begin{array}{l}\text { Singh et al. } \\
(2006)[9]\end{array}$ & $\begin{array}{l}\text { Analysis of reusable plastic containers and } \\
\text { display-ready corrugated containers used } \\
\text { for packaging fresh fruits and vegetables. }\end{array}$ & $\begin{array}{l}\text { Distribution within } \\
\text { the national } \\
\text { US market }\end{array}$ & $\begin{array}{l}\text { Non-foldable plastic } \\
\text { boxes (PP) } \\
\text { Cardboard boxes }\end{array}$ & $\begin{array}{l}\text { Ten different fresh } \\
\text { fruits and } \\
\text { vegetables }\end{array}$ \\
\hline 2007 & $\begin{array}{l}\text { Barthel et al. } \\
\text { (2007) [10] }\end{array}$ & $\begin{array}{c}\text { Analysis of the environmental impact of } \\
\text { the transport of fruit and vegetables } \\
\text { in Europe. }\end{array}$ & $\begin{array}{l}\text { International } \\
\text { distribution } \\
\text { across Europe }\end{array}$ & $\begin{array}{l}\text { Wooden boxes } \\
\text { Foldable plastic crates } \\
\text { (PP and HDPE) } \\
\text { Cardboard boxes }\end{array}$ & $\begin{array}{l}\text { Fresh fruits } \\
\text { and vegetables }\end{array}$ \\
\hline 2009 & $\begin{array}{l}\text { Albrecht et al. } \\
\text { (2009) [11] }\end{array}$ & $\begin{array}{l}\text { Update of the previous study. Analysis of } \\
\text { the environmental impact of the transport } \\
\text { of fruit and vegetables in Europe. }\end{array}$ & $\begin{array}{c}\text { International } \\
\text { distribution across } \\
\text { Europe }\end{array}$ & $\begin{array}{l}\text { Wooden boxes } \\
\text { Foldable plastic crates } \\
\text { (PP and HDPE) } \\
\text { Cardboard boxes }\end{array}$ & $\begin{array}{l}\text { Fresh fruits and } \\
\text { vegetables }\end{array}$ \\
\hline
\end{tabular}


Table 1. Cont.

\begin{tabular}{|c|c|c|c|c|c|}
\hline Year & $\begin{array}{l}\text { Author and } \\
\text { Reference }\end{array}$ & Goal of the Study & Geographic Scope & Containers Considered & $\begin{array}{l}\text { Products } \\
\text { Transported }\end{array}$ \\
\hline 2011 & $\begin{array}{l}\text { Levi et al. } \\
\text { (2011) [12] }\end{array}$ & $\begin{array}{l}\text { Comparison of the environmental impact } \\
\text { of disposable and reusable packaging of } \\
\text { fruit and vegetables in Italy. }\end{array}$ & $\begin{array}{l}\text { Distribution within } \\
\text { the Italian and } \\
\text { European market }\end{array}$ & $\begin{array}{l}\text { Foldable plastic crates } \\
\text { (PP) } \\
\text { Cardboard boxes }\end{array}$ & $\begin{array}{l}\text { Twelve types of } \\
\text { fruits and } \\
\text { vegetables }\end{array}$ \\
\hline 2013 & $\begin{array}{l}\text { Albrecht et al. } \\
\text { (2013) [13] }\end{array}$ & $\begin{array}{l}\text { A LCA of packaging systems for fruit } \\
\text { and vegetables. }\end{array}$ & $\begin{array}{l}\text { International } \\
\text { distribution } \\
\text { across Europe }\end{array}$ & $\begin{array}{l}\text { Wooden boxes } \\
\text { Foldable plastic crates } \\
\text { (PP and HDPE) } \\
\text { Cardboard boxes }\end{array}$ & $\begin{array}{l}\text { Fresh fruits and } \\
\text { vegetables }\end{array}$ \\
\hline 2015 & $\begin{array}{l}\text { Payen et al. } \\
(2015)[19]\end{array}$ & $\begin{array}{l}\text { Moroccan tomato export to the } \\
\text { French market. }\end{array}$ & $\begin{array}{l}\text { International } \\
\text { distribution from } \\
\text { Morocco to the } \\
\text { French market }\end{array}$ & Cardboard boxes & Tomatoes \\
\hline 2016 & $\begin{array}{l}\text { Franklin } \\
\text { Associates } \\
(2016)[14]\end{array}$ & $\begin{array}{l}\text { Comparative analysis of reusable plastic } \\
\text { containers and display and } \\
\text { non-display-ready cardboard containers. }\end{array}$ & $\begin{array}{l}\text { Distribution } \\
\text { throughout North } \\
\text { America }\end{array}$ & $\begin{array}{c}\text { Reusable plastic } \\
\text { containers (PP) } \\
\text { Display-ready corrugated } \\
\text { fiber containers } \\
\text { Non-display-ready } \\
\text { corrugated fiber } \\
\text { containers }\end{array}$ & $\begin{array}{l}\text { Ten different fresh } \\
\text { fruits and } \\
\text { vegetables }\end{array}$ \\
\hline 2017 & $\begin{array}{c}\text { Bala and } \\
\text { Fullana (2017) } \\
\text { [15] }\end{array}$ & $\begin{array}{l}\text { Comparative LCA of supply options for } \\
\text { fruit and vegetables in Spain. }\end{array}$ & $\begin{array}{l}\text { Distribution within } \\
\text { the Spanish national } \\
\text { market }\end{array}$ & $\begin{array}{l}\text { Foldable plastic crates } \\
\text { (PP and HDPE) } \\
\text { Cardboard boxes }\end{array}$ & $\begin{array}{l}\text { Fresh fruits and } \\
\text { vegetables }\end{array}$ \\
\hline 2020 & $\begin{array}{l}\text { Lo-Iacono et al. } \\
\qquad(2020) \text { [17] }\end{array}$ & $\begin{array}{l}\text { A carbon footprint assessment of the } \\
\text { transport of Spanish fruit and vegetables. }\end{array}$ & $\begin{array}{c}\text { International } \\
\text { distribution (from } \\
\text { Spain to Germany) }\end{array}$ & $\begin{array}{c}\text { Foldable plastic crates } \\
\text { (PP) } \\
\text { Cardboard boxes }\end{array}$ & $\begin{array}{l}\text { Six different fresh } \\
\text { fruits and } \\
\text { vegetables }\end{array}$ \\
\hline
\end{tabular}

This study shows the results of a comparative carbon footprint analysis of two of the most widely used fruit and vegetable packages for international transport: corrugated cardboard boxes and foldable plastic crates. Carbon footprint measurement and communication has been receiving much attention in recent years from the scientific community as well as from the companies who seek an accurate methodology to communicate the environmental impacts of their products, especially regarding climate change.

\subsection{The Product: Tomato}

In 2015, Payen et al. [19] conducted an LCA for Moroccan tomato exports to the French market, comparing it with local French off-season tomatoes. The focus of this study was to analyze the impact of freshwater use. The main conclusions of this study were that tomato cultivation's main impacts were in the water deprivation, freshwater eutrophication, ecotoxicity, and metal depletion impact categories, whereas tomato transport from Morocco to France was the main contributor to climate change terrestrial acidification, marine eutrophication, and fossil depletion. A year later, He et al. [20] carried out an LCA comparing data for conventional and organic greenhouse tomato production, concluding that organic production systems have positive effects from an environmental perspective, related mainly to the reduction of the use of synthetic fertilizers and pesticides, and providing suggestions for future research about the environmental implications of cold chain delivery. In 2019, Ronga et al. [21] conducted a carbon footprint and energetic analysis to investigate the actual environmental impact of processing tomato production both for organic and conventional cropping systems in Southern Italy. The study was limited to the production stage, not taking into consideration other stages of the life cycle, such as transport.

Other studies related to environmental aspects of fruit and vegetable supply chains were carried out by Finnan et al. (2002) [22], Prasad and Chakravorty (2015) [23], and Bisbis et al. (2018) [24].

In order to establish the origin and destination markets, Almería (in Spain), and Hamburg (in Germany), were chosen, since Almería is the location where the highest 
quantity of tomato is produced in Spain, and Germany is the main consumer of Spanish tomatoes. Hamburg is the center of gravity within the German market. The reasons for choosing Spain and Germany as origin and destination markets were due to the fact that according to the Spanish Federation of Associations of Producers and Exporters of Fruits, Vegetables, Flowers, and Live plants (FEPEX), Spain is the worldwide leader in the field of fruit and vegetable exports [25]. On the other side, in 2019, Germany was the main buyer of Spanish fruits and vegetables [25].

For this study, the tomato was selected as the product to be transported as it was the chosen product in numerous studies concerning the environmental impacts of agriculture. In addition, it is (apart from citrus fruits), the most exported product from the fruit and vegetable industry in Spain.

\subsection{The Study}

In 2018, the design and project management research group from Universitat Politècnica de València approached the comparative study of the CF according to ISO 14067:2018 [26] commissioned by the Institute for Sustainable Production (IPS) [27], seeking for conclusions regarding the two types of packaging systems most used in the refrigerated transport of fruit and vegetables by road.

The originality of this study comes from the fact that two of the most used packaging systems for the transport of fruit and vegetables all around the world were compared, from an environmental point of view, with special attention to their effects on climate change. Not only are the materials of the packaging systems different (corrugated cardboard and polypropylene), but also corrugated cardboard is used once whereas polypropylene boxes are reused between 20 and 50 times, as described further in Section 3.1.2 (Table 6). Due to aesthetic characteristics, boxes are not used more than 50 times. Moreover, this transport is carried out with packaging of two different sizes, both included in this study. This study also takes under consideration that some previous studies (see Table 1) refer to 50 and 100 uses, as some polypropylene box manufacturers claim that the life of their product is 100 uses. For comparative reasons only, this study also includes 100 uses.

The study was carried out along the life cycle of the packages, from cradle to grave, following ISO standards. ISO 14067:2018 established the requirements and guidance for quantification of the CF of products and refers to ISO 14026:2017 [28] for the communication of footprint information. The study underwent review by outside, qualified scientists, according to ISO TS 14071:2014 [29,30]. Moreover, a disclosure report is included in the study as complementary information. As required in Chapter 6 of ISO 14026:2017, this study also complies with the regulation regarding comparative studies defined by ISO 14044:2006 [31,32]. It must be highlighted that a CF of products presents the limitations of covering only one impact category, and better performance regarding climate change does not necessarily include overall better environmental performance.

The key environmental aspects of the analyzed products were identified, and main recommendations and suggestions proposed in order to reduce the GHG emissions associated with these products.

\section{Methods}

A CF study, according to the ISO 14067:2018 standard [28], must include the four phases of the LCA method (Figure 1). 


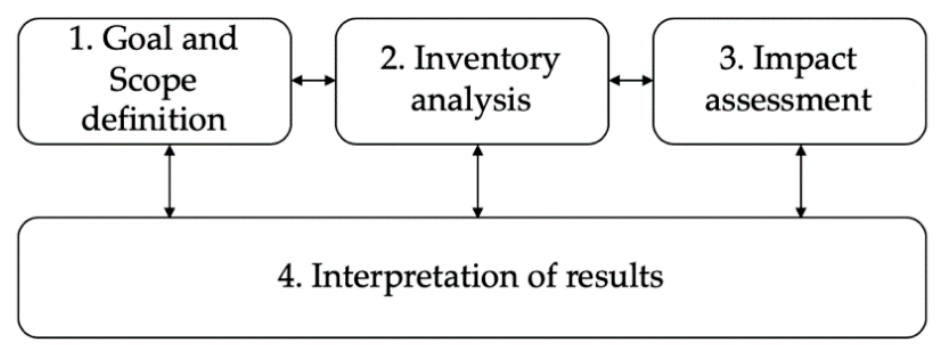

Figure 1. LCA method [31].

\subsection{Goal and Scope Definition}

In the definition of the goal, as indicated in Section 6.3 of standard ISO 14067:2018, the intended application, the reasons for conducting the study, the target audience, and whether it is planned to use the results in comparative analyses that will be disclosed to the public should be specified without ambiguity. According to the standard, the scope definition must include the following aspects:

- Product system and its functions;

- Functional unit;

- System limit, including the geographic scope;

- Data and data quality requirements;

- Assignment procedures;

- Time limit for data;

- Assumptions, especially for the use stage and for the end-of-life stage;

- Emissions and elimination of specific GHG;

- Methods to deal with problems that occur with specific product categories;

- Selected impact categories, the impact assessment methodology, and the subsequent interpretation to be used;

- Type and format of the report required for the study;

- Type of critical review, if any; and

- Study limitations, according to Annexes B and D of the standard.

\subsection{Inventory Analysis}

Inventory analysis refers to the collection of data and calculation procedures to quantify the inputs and outputs to the product system throughout its life cycle.

The steps to follow are:

- Data collection;

- Validation of collected data; and

- Relating the data to the unit processes and the functional unit.

In addition, at this stage, decisions will have to be made based sometimes on sensitivity analysis of the data that may affect the limits of the study (which should be reviewed if necessary). The inputs and outputs must be assigned according to the procedures specified in the scope.

\subsection{Impact Assessment}

The potential climate change impact of each GHG emitted and eliminated must be calculated by multiplying the mass of GHG released or eliminated by the global warming potential (GWP) of 100 years provided by the Intergovernmental Panel on Climate Change (IPCC) in units of " $\mathrm{kg} \mathrm{CO} 2$ equivalent per $\mathrm{kg}$ of emission."

When the GWP values are corrected by the IPCC, the most recent values should be used in the CF calculations. 


\subsection{Interpretation of Results}

The interpretation of the results is the last phase, where the results of the inventory analysis and the impact assessment are considered together. This phase must include the following elements:

- Identification of significant emissions based on the results of the quantification of the life cycle inventory analysis and life cycle impact assessment phases of a CF;

- Evaluation that includes verifications of the integrity, sensitivity, and coherence analyses; and

- Conclusions, limitations, and recommendations.

The interpretation must:

- Include a quantitative and/or qualitative evaluation and uncertainty, including the application of rounding rules or ranges;

- Identify and document in detail the allocation methods selected in the report; and

- Identify the limitations of the study (according to Annex B of the standard).

In a LCA, the category that measures the environmental impact due to GHG emissions is commonly referred to as global warming or climate change potential, according to the method used. In analyses that take into consideration only one category of impact, specifically the impact due to GHG emissions, the final result of the impact is often referred to as "carbon footprint." The CF can therefore be considered an analysis of the life cycle in which the results are obtained only for one impact category.

The concept of a CF is not limited to the measurement of emitted carbon dioxide but also takes into consideration in its calculation all the gases that can contribute to generating the greenhouse effect and that are included in the Kyoto Protocol [33]. The CF is obtained by converting the individual results of each gas to its $\mathrm{CO}_{2}$ equivalent and expressing the total result in equivalent kilograms of $\mathrm{CO}_{2}$. Consequently, the correct term for the indicator is "carbon footprint equivalent," although in practice, "carbon footprint" is used for simplicity. The conversion of each gas to its $\mathrm{CO}_{2}$ equivalent $(\mathrm{CO} 2 \mathrm{e})$ is done through the characterization factors.

For the determination of the $\mathrm{CF}$ associated with products, the Intergovernmental Panel on Climate Change (IPCC) methodology was used [34]. It was developed by the World Meteorological Organization and the United Nations Environment Program and supported by the United Nations Framework Convention on Climate Change. The method contemplates different time horizons $(20,100$, and 500 years) when determining the global warming potential of the different substances considered GHG [35].

\subsection{Disclosure Report and Critical Review}

When a CF study developed by ISO 14067:2018 standard is made publicly available, the requirements of ISO 14026:2017 must be met. Chapter 6 of ISO 14026 defines the requirements for communications; this report is also included as Appendix A of this paper.

A critical review was carried out by a review panel composed of four experts. Two of the members were from a research center specializing in environmental assessment and the other two were expert university professors specializing in LCA following the requirements of ISO 14044:2006 and ISO TS 14071:2014 identified in ISO 14026:2017.

\section{Results and Discussion}

Following the standard, this section presents each of the results obtained in the development of the calculation of the $\mathrm{CF}$.

\subsection{Goal and Scope Definition}

The main objective was the determination of the CF of the containers used in the refrigerated transport of fruit and vegetable products for export. Both reusable and foldable plastic containers made of polypropylene (PPB) and corrugated cardboard (CCB) containers were studied. To do so, the CF associated with each typology of PPB and CCB considered 
were calculated in order to make visible in a particular way the potential contribution to global warming of each type of container in tons of $\mathrm{CO}_{2} \mathrm{e}$. The results of the CF study of each package were compared later for evaluation. In order to make this comparison and follow the regulations, the study was subjected to a critical review under the premises of ISO 14044 and ISO TS 14071:2014.

The tomato was selected as the product because it is the main export product of the Almería region, the main producer of tomatoes in Spain. According to FEPEX [25] in 2019, 767 kilotons of tomatoes from Spain were exported for more than EUR 920 million-6.8\% of exports of all fruits and vegetables produced in Spain. As a destination, the German market was selected, as $26.54 \%$ of Spanish tomato production was exported to Germany [25].

The scope definition includes the product system definition. Corrugated cardboard containers are the most used in the market for the transport of this type of product. Reusable and foldable plastic containers made of polypropylene are also widely used for the transport of fruit and vegetable products. Two different sizes of boxes are used for tomatoes in the European market; both sizes were considered in the sensitivity analysis of this study as their composition and behavior are different [17]. Table 2 collects the characteristics of the boxes.

Table 2. Product system characteristics and codification.

\begin{tabular}{ccccc}
\hline Box Type & $\begin{array}{c}\text { Dimensions When } \\
\text { Use } \mathbf{( m m}^{\mathbf{3}} \mathbf{)}\end{array}$ & $\begin{array}{c}\text { Folded Height } \\
\mathbf{( m m )}\end{array}$ & $\begin{array}{c}\text { Weight } \\
\mathbf{( k g )}\end{array}$ & $\begin{array}{c}\text { Maximum } \\
\text { Capacity } \mathbf{( k g )}\end{array}$ \\
\hline PPB6 & $600 \times 400 \times 101$ & 34.3 & 1.170 & 6 \\
PPB4 & $400 \times 300 \times 167$ & 34.3 & 0.920 & 7 \\
CCB6 & $600 \times 400 \times 101$ & 7.0 & 0.478 & 7 \\
CCB4 & $400 \times 300 \times 145$ & 7.0 & 0.319 & 6 \\
\hline
\end{tabular}

The function of the packages analyzed in this study was to serve as a container and transport the different products evaluated from their home market to the different destination markets considered in the analysis. The subsequent service that the box provided at the points of sale (as a display-ready container) once at the destination was not in the scope of the analysis. As for the distances considered for the analysis, the average distance to destination, $2500 \mathrm{~km}$, was taken into consideration.

Since the function of the package is to transport the product from the market of origin to the destination market in good condition, the functional unit considered for the analysis was a packaging system to properly store and transport $1000 \mathrm{t}$ of product from the market of origin, located mainly in Almería, to the destination market. The function includes the service provided by the box from the moment the product is packaged until it arrives at the distribution center and includes the stages of manufacture and end of life of the container once its useful life has ended.

Considering the characteristics of the packages, and to satisfy the functional unit, the following reference flows were determined (Table 3). The fruit and vegetable packaging companies provided the actual load data.

Table 3. Reference flows for the product distribution stage considered by type of package.

\begin{tabular}{cccc}
\hline Type of Box & Maximum Capacity (kg) & Real Load (kg) & Total Number of Boxes/Uses * \\
\hline PPB6 & 6 & 6 & 166,667 \\
PPB4 & 7 & 6 & 166,667 \\
CCB6 & 7 & 7 & 142,858 \\
CCB4 & 6 & 6 & 166,667 \\
\hline *In "uses" when assessing PPB, as one box can be used more than one time, as considered in this study.
\end{tabular}

System limits are defined through the product life cycle analysis. For this study, it was a cradle-to-grave analysis. 
For PPB it included the stages of manufacturing in Spain (obtaining raw material, transport of the raw material, manufacture of the boxes, and transport to the packaging centers), transport of the product to the German market, return transport of the PPB to the sanitation centers located in Spain, PPB sanitation, and end-of-life management (both in Spain and in the country of destination, depending on where the box was removed). For $\mathrm{CCB}$, it included the manufacturing stage of corrugated cardboard (obtaining raw material, transport, manufacture of the box, and transport to the packaging center), transport of the product to the country of destination, and management of the end of life of the box. Figures 2 and 3 describe the life cycle of the boxes considered, including the description of transport.

Crude oil extraction +
Monomer and pellet manufacturing

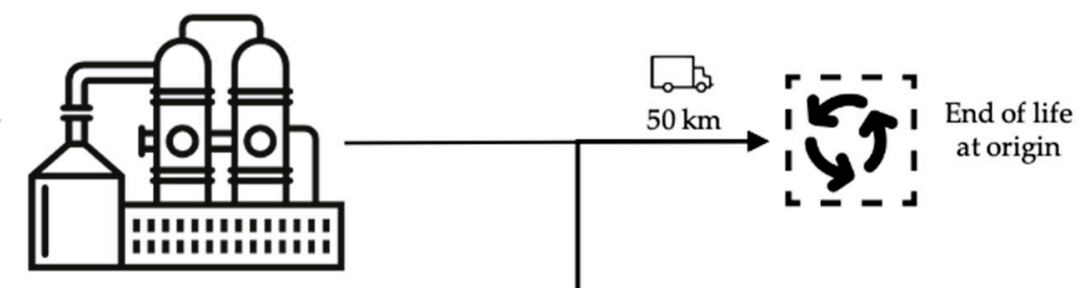

Box manufacturing
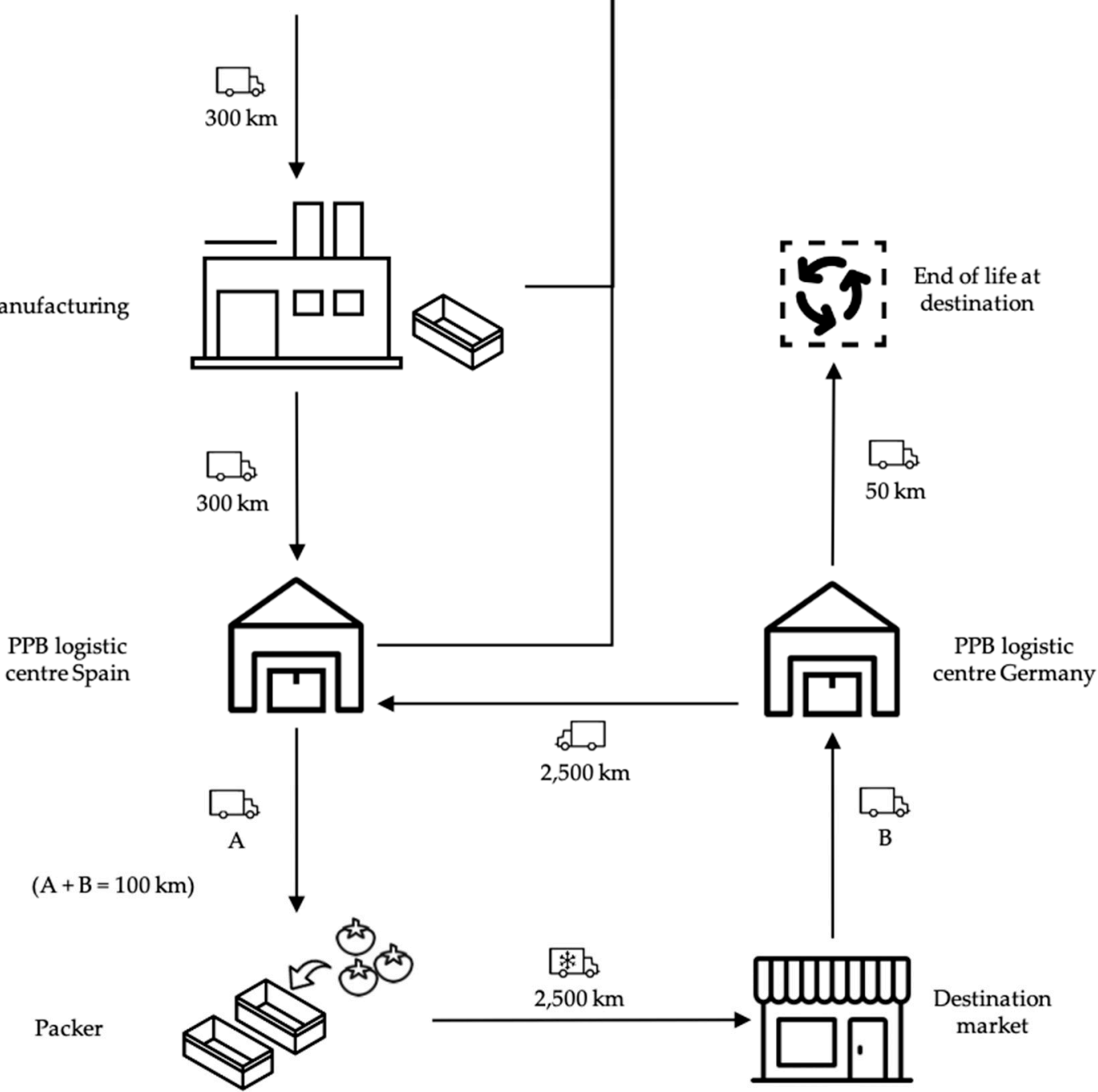

Figure 2. Life cycle of PPB boxes used for the refrigerated transport of tomatoes from Spain to Germany. 


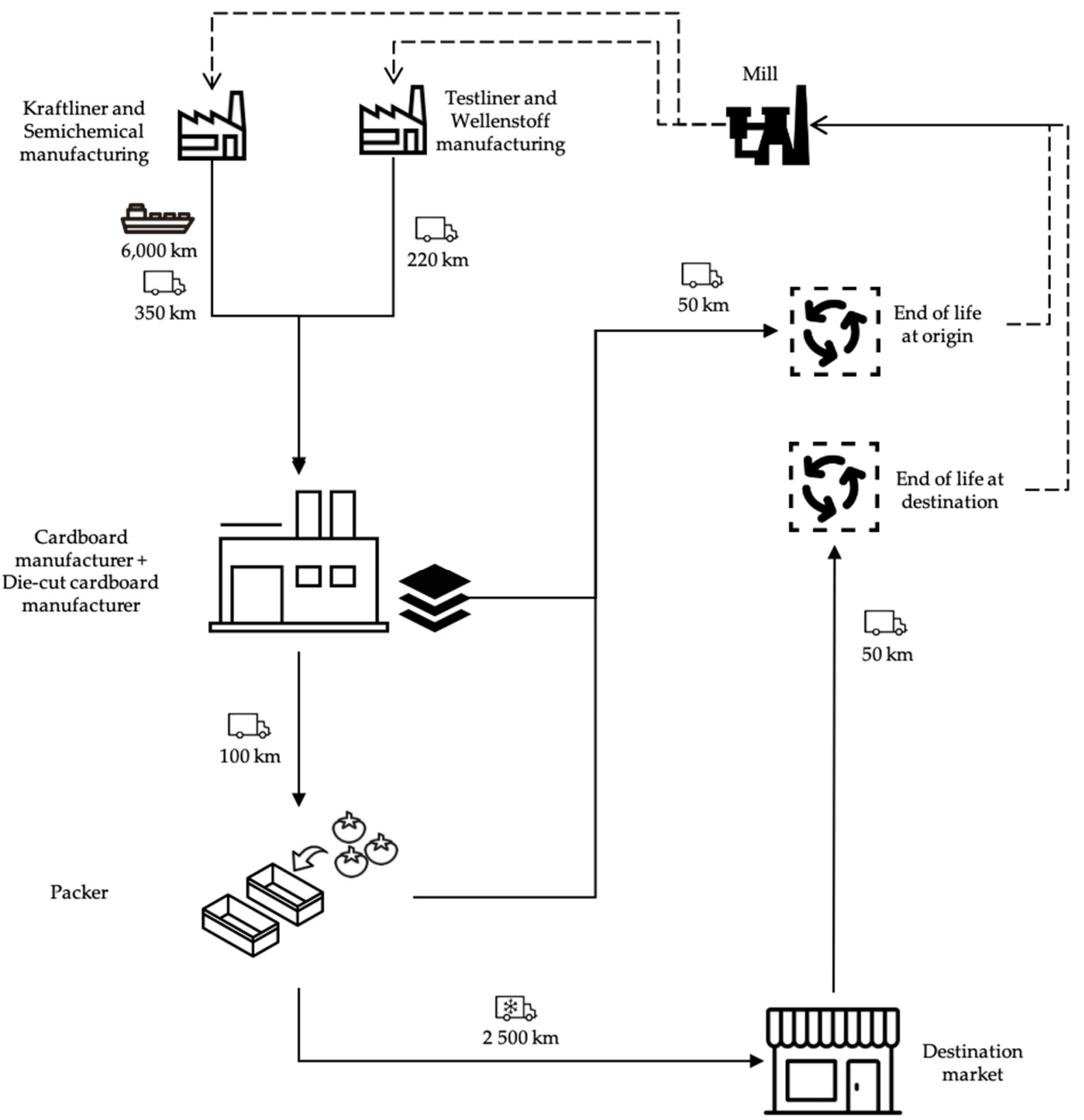

Figure 3. Life cycle of CCB boxes used for the refrigerated transport of tomatoes from Spain to Germany [17].

For the inventory, the so-called cutting rules were applied. Individual entries that constituted very small percentages of the total inputs to the system, such as pallets and lowdensity polyethylene film, were excluded from the packaging, strapping, and palletizing activities of the boxes and the screening, treatments, cleaning, and packaging carried out in the warehouse of entry of the fruit and vegetable products and the transport of the fruit and vegetable products.

As indicated in ISO 14044, the cutting criteria can be applied to the criteria of mass, energy, or environmental importance. In this case, it was decided to apply it to the mass criterion and in some specific cases to the energy criterion. Thus, entries that did not involve a relative contribution of more than $5 \%$ were excluded from the study. This cutting criterion was applied to raw materials for which no data was obtained and also represented less than $5 \%$ of the total mass of raw materials (logo printing inks, plastic dyes, and additives), in the consumption of energy and materials in warehouses, and in the film used in palletizing and packaging at the stage of manufacturing the boxes. It should be noted that printing inks and additives are regulated for packaging in contact with food. Therefore, these substances 
were considered in the regular cut-off criteria as they are non-toxic [36-38]. In addition, infrastructure was left out of the scope of the study.

Whenever possible, the study data were taken by direct quantification. When this was not possible, data from government agencies and/or recognized institutions, manufacturer data sheets, and proven bibliographic sources were used. In cases where this type of field information was not available, the Ecoinvent 3.01 databases were used [35]. The data was processed with the SimaPro version 8.0.1 software.

The quality of the most relevant data used to calculate the $\mathrm{CF}$ was evaluated according to the International Reference Life Cycle Data System (ILCD) Handbook [39]. In this analysis, a set of indicators are evaluated with a quality ratio between 0 and 5 , where 0 stands for "not applicable," 1 stands for representatively higher than $95 \%, 2$ between $85 \%$ and $95 \%, 3$ between $75 \%$ and $85 \%, 4$ between $50 \%$ and $75 \%$, and 5 under $50 \%$. The indicators used were:

TeR: degree of technical representativeness;

GR: degree of geographical representativeness;

TiR: degree of temporal representativeness;

C: completeness, defined as the proportion of elementary flows that were quantified in the inventory;

P: precision/uncertainty; and

M: methodological adequacy and consistency.

The data quality requirement level (DQR) represented by Equation (1) [39] was also calculated:

$$
D Q R=\frac{\mathrm{TeR}+\mathrm{GR}+\mathrm{TiR}+C+P+M+X_{w} * 4}{i+4}
$$

where $X_{w}$ corresponds to the most unfavorable level of all indicators and $i$ represents the number of applicable indicators. Table 4 shows the values for each input flow considered: its source and its DQR.

Table 4. Data quality indicators according to the ILCD Handbook [39].

\begin{tabular}{|c|c|c|c|c|c|c|c|c|c|}
\hline Input Data/Flows & TeR & GR & TiR & C & $\mathbf{P}$ & $\mathbf{M}$ & Source & & DQR \\
\hline $\begin{array}{c}\text { Sizes, maximum capacities, weight, and raw material of } \\
\text { the PPB }\end{array}$ & 0 & 1 & 1 & 2 & 2 & 2 & {$[40,41]$} & 1.78 & Basic quality \\
\hline $\begin{array}{c}\text { Sizes, maximum capacities, weight, and composition of } \\
\text { the CCB }\end{array}$ & 0 & 1 & 1 & 2 & 2 & 2 & $\begin{array}{l}\text { CCB manufacturers } \\
\text { with UNIQ seal [42] }\end{array}$ & 1.78 & Basic quality \\
\hline Polypropylene for boxes & 3 & 2 & 2 & 2 & 3 & 2 & {$[41]$} & 2.60 & Basic quality \\
\hline Environmental data of raw materials for boxes & 2 & 1 & 1 & 1 & 2 & 1 & {$[41,42]$} & 1.60 & High quality \\
\hline $\begin{array}{l}\text { Actual load capacities of the boxes according to the fruit and } \\
\text { vegetable products to be transported }\end{array}$ & 1 & 3 & 0 & 2 & 1 & 1 & $\begin{array}{l}\text { Export companies } \\
\text { from Almería }\end{array}$ & 2.22 & Basic quality \\
\hline Internal transport & 3 & 3 & 2 & 2 & 3 & 2 & $\begin{array}{l}\text { Export companies } \\
\text { from Almería }\end{array}$ & 2.70 & Basic quality \\
\hline Electric supply model & 0 & 2 & 2 & 1 & 2 & 2 & {$[35,43]$} & 1.89 & Basic quality \\
\hline Cardboard manufacturing and die-cutting processes & 2 & 1 & 1 & 2 & 2 & 2 & {$[42,44]$} & 1.8 & Basic quality \\
\hline Internal transport fuel & 0 & 3 & 3 & 2 & 2 & 2 & [35] & 2.67 & Basic quality \\
\hline Machinery or injection process & 1 & 2 & 2 & 2 & 3 & 2 & {$[35,41,45]$} & 2.40 & Basic quality \\
\hline Sanitizing process & 3 & 3 & 2 & 2 & 3 & 2 & {$[46,47]$} & 2.70 & Basic quality \\
\hline Trucks for the transport of raw materials and boxes & 2 & 2 & 2 & 2 & 2 & 2 & [35] & 2.00 & Basic quality \\
\hline Emission factors for maritime transport modeling & 0 & 2 & 1 & 1 & 2 & 2 & [48] & 1.78 & Basic quality \\
\hline Emission factors for road transport modeling & 0 & 2 & 1 & 1 & 2 & 2 & [49] & 1.78 & Basic quality \\
\hline Distance to destination country & 0 & 2 & 1 & 2 & 3 & 2 & {$[50,51]$} & 2.44 & Basic quality \\
\hline Percentage of losses and/or breaks for PPB & 0 & 2 & 1 & 2 & 2 & 2 & {$[10,14]$} & 1.89 & Basic quality \\
\hline Percentage of losses and/or breaks for CCB & 2 & 1 & 1 & 1 & 2 & 1 & [42] & 1.60 & High quality \\
\hline Rotations/use of PPB & 0 & 2 & 1 & 2 & 2 & 2 & {$[10,14,52]$} & 1.89 & Basic quality \\
\hline $\begin{array}{l}\text { Percentage distribution of waste management treatments of } \\
\text { plastic containers }\end{array}$ & 0 & 1 & 1 & 1 & 2 & 2 & [53] & 1.67 & Basic quality \\
\hline End-of-life treatments & 3 & 3 & 3 & 3 & 3 & 3 & [35] & 3.00 & Basic quality \\
\hline
\end{tabular}

The time limit for the data was the period of time for which the measured figure for the $\mathrm{CF}$ was representative. 
In this study, the data collected in the inventory phase of the corresponding PPB covered the period of time from 2015, for data related to energy and injection processes, up to the period from 1999 to 2013, in the case of eco-profiles of plastics (extracted from the Ecoinvent 3.01 database, compiled, and reviewed at the end of 2013). For CCB, they covered the period of time from 2014 in the case of road transport emission factors and waste management scenarios in each country until 2017, corresponding to the consumption of the machinery used in the manufacturing process of the CCB.

\subsubsection{Assumptions}

The study considered different stages of transport and different vehicles, each with a different consumption depending on the type of cargo it carried. The stages of road transport considered in the life cycle of PPB are illustrated in Figure 2:

- Transport of raw materials to the PPB manufacturer in non-refrigerated trucks of $40 \mathrm{t}$ of maximum authorized weight and $16 \mathrm{t}$ tare weight;

- Transportation from the PPB manufacturer to the PPB sanitation and storage company in non-refrigerated trucks of $40 \mathrm{t}$ maximum authorized weight and $16 \mathrm{t}$ tare weight;

- Transportation of the PPB from the storage center to the packing facilities in nonrefrigerated trucks of $40 \mathrm{t}$ maximum authorized weight and $16 \mathrm{t}$ tare weight;

- Transportation of the PPB loaded with the product from the country of origin to the different destination countries in refrigerated trucks of $40 \mathrm{t}$ maximum authorized weight and $16 \mathrm{t}$ tare weight;

- Transportation of used, empty, and folded PPB to sanitation and storage centers in non-refrigerated trucks of $40 \mathrm{t}$ maximum authorized weight and $16 \mathrm{t}$ tare weight; and

- Transportation of PPB that was no longer useful to the different waste management centers in non-refrigerated trucks of $16 \mathrm{t}$ maximum authorized weight and $6.5 \mathrm{t}$ tare weight.

For CCB, the stages of road transport were extracted from a previous study [17] with the following assumptions:

- Transport of raw materials (paper reels) to the manufacturer of the CCB in nonrefrigerated trucks of $40 \mathrm{t}$ maximum authorized weight and $16 \mathrm{t}$ tare weight;

- Transportation of the CCB manufacturer to the packing facilities in non-refrigerated trucks of $40 \mathrm{t}$ maximum authorized weight and $16 \mathrm{t}$ tare weight;

- Transport of the CCB loaded with the product from the country of origin to the different destination countries in refrigerated trucks of $40 \mathrm{t}$ maximum authorized weight and $16 \mathrm{t}$ tare weight; and

- Transport of the CCB that was no longer useful to the different waste management centers in non-refrigerated trucks of $16 \mathrm{t}$ maximum authorized weight and $6.5 \mathrm{t}$ tare weight.

Different types of trucks were used depending on the life cycle. The data, taken from the European Monitoring Evaluation Program of the European Environment Agency [49], considered Tier 1 emissions. The types of trucks considered in the life cycles were:

- $16 \mathrm{t}$ non-refrigerated truck for transporting containers to waste management centers;

- $40 \mathrm{t}$ non-refrigerated truck for transporting raw materials and boxes manufactured to the storage center and packing center, and boxes used from the country of destination to the sanitation and storage centers; and

- $40 \mathrm{t}$ refrigerated truck to transport products to their different destination markets.

Depending on the load to be transported, and after consulting different logistics companies, the consumptions depending on the type of truck and their load were considered for the analysis. For non-refrigerated trucks of $16 \mathrm{t}$, the consumption is $24 \mathrm{~L} / 100 \mathrm{~km}$ when the load transported is $9.5 \mathrm{t}$. For non-refrigerated trucks of $40 \mathrm{t}$ the consumption has more variation depending on the load transported. For example, between $20 \mathrm{t}$ and $23 \mathrm{t}$, the consumption is $33 \mathrm{~L} / 100 \mathrm{~km}$. A reduction of $1 \mathrm{~L} / 100 \mathrm{~km}$ was contemplated for the range from $15 \mathrm{t}$ to $19 \mathrm{t}$. An additional reduction of $1 \mathrm{~L} / 100 \mathrm{~km}$ was considered for loads of $10 \mathrm{t}$ to 
$14 \mathrm{t}$. Finally, $30 \mathrm{~L} / 100 \mathrm{~km}$ was considered for loads of $8 \mathrm{t}$ to $9 \mathrm{t}$. When refrigerated trucks of $40 \mathrm{t}$ were assessed, a similar consideration was given to their consumption: $36 \mathrm{~L} / 100 \mathrm{~km}$ for loads between $23 \mathrm{t}$ and $20 \mathrm{t}, 35 \mathrm{~L} / 100 \mathrm{~km}$ for loads between $19 \mathrm{t}$ to $15 \mathrm{t}, 3 \mathrm{~L} / 100 \mathrm{~km}$ for loads between $14 \mathrm{t}$ and $10 \mathrm{t}$, and $33 \mathrm{~L} / 100 \mathrm{~km}$ for loads between $9 \mathrm{t}$ and $8 \mathrm{t}$.

It should be noticed that in the refrigerated trucks the compressor must continue working during the driver's rest stops.

In the different stages of manufacturing and handling the boxes, an internal transport with forklifts was considered inside the industries through which the goods are transferred. In general, this type of transport is carried out by forklifts with a load capacity of up to $1500 \mathrm{~kg}$. These trucks act fully loaded and each trip lasts approximately $60 \mathrm{~s}$. Two types of forklifts (electric, which makes $67 \%$ of displacements, and diesel engines, which make $33 \%$ of displacements) were defined according to the data collected from different companies interviewed (Table 5).

Table 5. Information regarding forklifts for the internal transport of PPB in industries.

\begin{tabular}{ccc}
\hline & Diesel Forklift & Electric Forklift \\
\hline Maximum load capacity $(\mathrm{kg})$ & 1500 & 1500 \\
Full load power & $2.3 \mathrm{~L} / \mathrm{h}$ & $4.1 \mathrm{~kW}$ \\
Activity time $(\mathrm{s})$ & 60 & 60 \\
No. of trips & 4 & 4 \\
Source of information for the environmental & {$[35]$} & {$[43]$} \\
damage model & & \\
\hline
\end{tabular}

The other assumptions of the study were related to the end-of-life stage. The end-oflife stage begins when the used boxes are ready for disposal, recycling, etc. In the study it was considered that all the boxes considered in the complete cycle, associated with the functional unit, are managed in the waste treatment plants.

As to where the waste is managed, it was assumed that all the boxes necessary for the transport of fruit and vegetable products are managed at the end of their useful life (either due to aesthetic degradation, inability to remove residues from adhesive plastic labels, loss of functionality, etc.) in the country where sanitation and storage is carried out in the case of PPB (since that is where quality control is also carried out). It was considered that $50 \%$ of said losses/breakages occur in the country of origin and the other $50 \%$ occurs in the country of destination, because at both sites the boxes are opened and closed in the packaging centers, at the points of sale, and in the sanitation and storage centers, which can lead to breakage of the boxes. In the case of CCB the percentage of breakage is $0.1 \%$ and occurs during assembly in the packaging center, so it is managed in Spain. The end of life, on the other hand, takes place in the country of destination (Germany), where the management of the box is carried out as waste.

Recycling was considered as an allocation problem, which may imply that GHG emissions associated with unit processes for the extraction and processing of raw materials and unit processes for the final disposal of products, including recycling, are shared by more than one product system [26]. The allocation procedure used for shared unit processes was the closed cycle. ISO 14044:2006 establishes that the closed-circuit procedure can be applied to open circuit systems when the recycled material has the same inherent properties of the primary material. In this case the GHG emissions of the unit processes for the final disposal of the product, including recycling, are assigned to the product that delivers the recycled material, but the recycled material that leaves the product system carries a recycling credit that corresponds to GHG emissions from the acquisition of primary material.

In the case of the PPB, no recycled material is used in the manufacturing stage and therefore it is understood that the boxes will subsequently be recycled (in the specified percentage of the country) and the emissions linked to end-of-life operations and recyclingrelated credits are accounted for at the end-of-life stage of the analyzed cycle. On the other hand, for CCB, recycled paper fibers are used in the manufacturing stage, and therefore 
it is considered that in the end-of-life treatment there is a specific recycling percentage determined by the country. The emissions linked to recycling are not accounted for at the end-of-life stage analyzed, since credit is considered at the manufacturing stage.

\subsubsection{Sensitivity Analysis}

The sensitivity analysis is justified when different scenarios are proposed based on criteria linked to the possibility of process improvements or data quality. Regardless of the general CF calculation, two variables were considered:

- Box size; and

- Number of rotations/uses.

In relation to the box size, as two different sizes are often used, as described in the introduction, an analysis of the influence of the size was developed.

Regarding when rotations are analyzed, there is a diversity of opinions in previous studies. The study carried out by Stuttgart University and financed by Stiftung Initiative Mehrweg (a German foundation that promotes the use of reusable packages) defined the number of uses as between 50 and 100 [11], and the study developed by the Fraunhofer Institut für Materialfluss und Logistik [52] defined a lifetime for PPB of between 10 to 20 years and a rate of 5 shipments per year that vary between 20 and 100 rotations. In 2017, a study that developed an LCA of the operations of the IFCO group in a North American market applied an average of 39 uses per box [14]. To understand this hypothesis, in this study the assumptions shown in Table 6 regarding the duration of processes were considered. This meant that a box could be used between seven and nine times per year, and 50 cycles implied six or seven years of use with perfect appearance.

Table 6. Analysis of the duration of each use of PPB.

\begin{tabular}{cc}
\hline Operation/Place & Average Duration (Days) \\
\hline Stock (packer or producer) & 15 \\
Traveling to the selling point & $1-2$ \\
At the store (display-ready boxes) & $5-7$ \\
At store storage, folded, waiting for the return trip & 1 \\
At the sanitation center & 1 \\
Stock (storage center) & $15-\mathbf{2 0}$ \\
Traveling for replacement & 1 \\
Total & $\mathbf{3 4 - 4 7}$ \\
\hline
\end{tabular}

Given that tomatoes have an international campaign of 270 days a year, six to eight rotations per year are needed. A lifetime of seven years implies between 42 and 56 uses. However, the aesthetic factor of these type of "display-ready" boxes is essential. Therefore, the number of uses considered was between a minimum of 20 and a maximum of 50 . Twenty uses represents the scenario where boxes are used an average of four times a year for five years. This is the case when final customers are critical of the aesthetic aspect of the display-ready box used in their markets and that contains fruit and vegetables with a short season (three to four month a year). Fifty uses is the most likely scenario and represents a box with 10 uses per year over five years or five uses over 10 years. After this time, the appearance of the box is not suitable for the market. An extreme case is included in this study, with 100 uses for comparative purposes, since other studies usually considered this option, despite the fact that it is very difficult for a plastic box to preserve its aesthetic conditions for more than 15 or even 20 years. The results allow an analysis of the influences of these variables on the environmental impact of the analyzed transport.

\subsection{Inventory Analysis}

Inventory analysis involves the collection of data and calculation procedures to quantify the relevant inputs and outputs of the product system for the entire life cycle (Figures 2 and 3). In this section, the detailed inventory analysis for each box is described. 


\subsubsection{Inventory Analysis for PPB}

The cycle of PPB begins by obtaining the raw material for the boxes, the polypropylene pellet. It should be notice that the polypropylene used is virgin. Due to the level of cleaning required for packaging in contact with food, recycled polypropylene, often printed or colored, is not suitable [54].

Then the raw materials are transported to the industries responsible for the manufacturing of the boxes. This transport is carried out in non-refrigerated trucks of $40 \mathrm{t}$ an average distance of $300 \mathrm{~km}$ (Figure 2). The injection process, the internal transport of raw material and manufactured boxes, the transport of the PPB to the sanitation and storage center, and the internal transport of the boxes in the packaging center were considered in the manufacture of the PPB. The percentage of losses in the extruder, mold injection pipe, injection bottom, and cuttings are considered to be $1.6 \%$.

For internal transport, the weight to be transported of the raw material and of the different boxes, the number of boxes required to transport the $1000 \mathrm{t}$, the number of cycles of use of each box, as well as the percentage of boxes that are lost or broken in each cycle ( $1 \%$ to $5 \%$, depending on number of uses of rotations) and must be replaced, were all taken into consideration. The weight of the raw material per box is $1.188 \mathrm{~kg}$. The weight of the boxes is $1.170 \mathrm{~kg}$. To transport $1000 \mathrm{t}$ of tomatoes, 166,667 boxes are needed without considering cycles of use or percentage of losses and breakages. Figure 4a shows the unitary PPB manufacturing process.

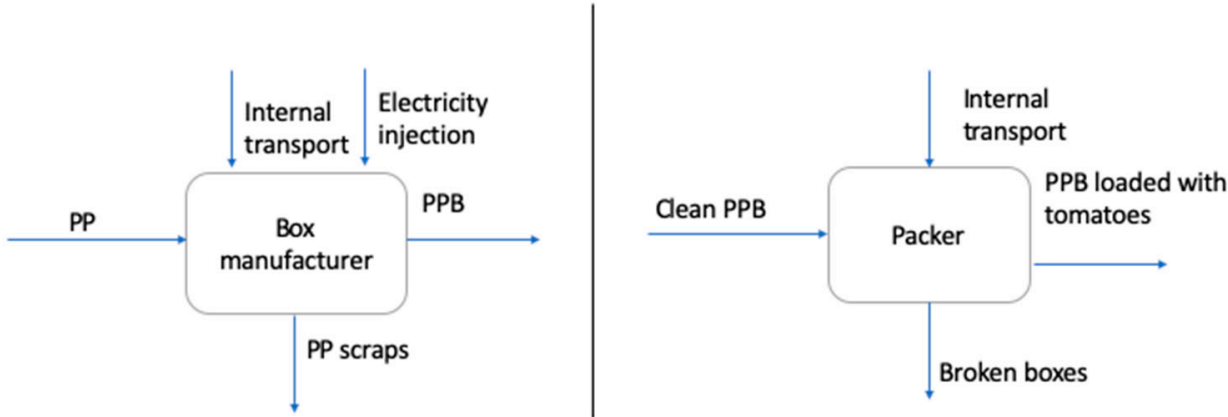

Figure 4a. Box manufacturing

Figure 4b. Packaging center

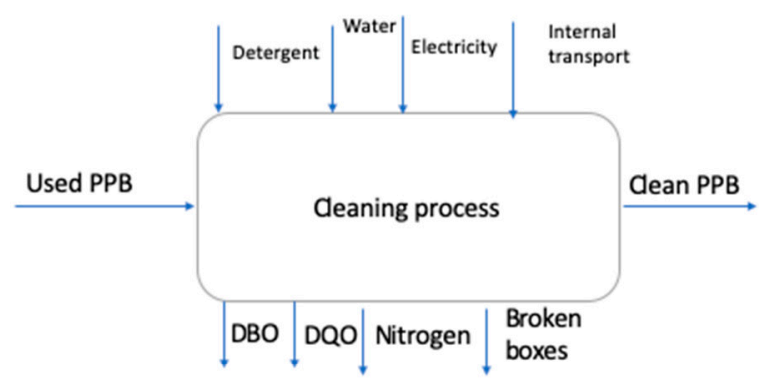

Figure 4c. Sanitation

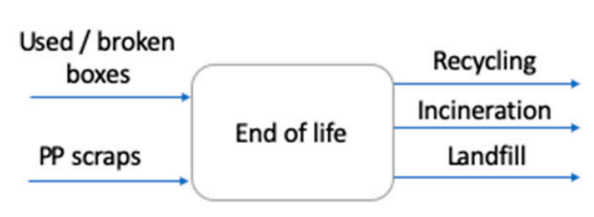

Figure 4d. End-of-life at origin

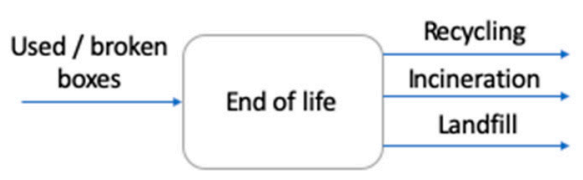

Figure 4e. End-of-life at destination

Figure 4. Unit processes. (a). Box Manufacturing, (b). Packaging center, (c) Sanitation, (d). End-of-life at origin, (e). End-oflife at destination. 
Once manufactured, the boxes are transported folded to the sanitation and storage centers, and from there they are distributed to the packaging centers. This transport is carried out in non-refrigerated trucks of $40 \mathrm{t}$ and with an average distance of $300 \mathrm{~km}$, considering that in each truck there are 33 pallets, 60 rows of folded boxes, and 4 boxes per row for PPB (see Tables 7-9 for more details).

Table 7. Transport of boxes to sanitation.

\begin{tabular}{ccc}
\hline Box Type & Boxes Per Truck & Total Trips Needed \\
\hline PPB6 & 7920 & 21.04 \\
PPB4 & 15,840 & 10.52 \\
\hline
\end{tabular}

Table 8. Distribution of loaded boxes.

\begin{tabular}{ccccccccc}
\hline $\begin{array}{c}\text { Box } \\
\text { Type }\end{array}$ & $\begin{array}{c}\text { Rows of } \\
\text { Boxes per } \\
\text { Pallet }\end{array}$ & $\begin{array}{c}\text { Boxes } \\
\text { per Row }\end{array}$ & $\begin{array}{c}\text { Pallets per } \\
\text { Truck }\end{array}$ & $\begin{array}{c}\text { Actual Load } \\
\text { per Box (kg) }\end{array}$ & $\begin{array}{c}\text { Boxes per } \\
\text { Truck }\end{array}$ & $\begin{array}{c}\text { Boxes to } \\
\text { Transport }\end{array}$ & $\begin{array}{c}\text { Total Load (Boxes + } \\
\text { Product) to Be } \\
\text { Transported by Truck (t) }\end{array}$ & $\begin{array}{c}\text { Number of } \\
\text { Trucks or Trips } \\
\text { to Carry to } \\
\text { Transport 1000 t }\end{array}$ \\
\hline PPB6 & 20 & 4 & 33 & 6 & 2640 & 166,667 & 18.93 & 63.13 \\
PPB4 & 12 & 8 & 33 & 6 & 3168 & 166,667 & 21.92 & 52.61 \\
\hline
\end{tabular}

Table 9. Transport information of folded used plastic boxes.

\begin{tabular}{ccccccccc}
\hline $\begin{array}{c}\text { Box } \\
\text { Type }\end{array}$ & $\begin{array}{c}\text { Rows of } \\
\text { Boxes per } \\
\text { Pallet }\end{array}$ & $\begin{array}{c}\text { Boxes } \\
\text { per Row }\end{array}$ & $\begin{array}{c}\text { Pallets per } \\
\text { Truck }\end{array}$ & $\begin{array}{c}\text { Box Weight } \\
\text { (kg) }\end{array}$ & $\begin{array}{c}\text { Boxes per } \\
\text { Truck }\end{array}$ & $\begin{array}{c}\text { Boxes to } \\
\text { Transport }\end{array}$ & $\begin{array}{c}\text { Loading of Boxes } \\
\text { per Truck (t) }\end{array}$ & $\begin{array}{c}\text { Number of Trucks or } \\
\text { Trips to Carry all the } \\
\text { Boxes }\end{array}$ \\
\hline PPB6 & 60 & 4 & 33 & 1.170 & 7920 & 166,667 & 9.27 & 21.04 \\
PPB4 & 60 & 8 & 33 & 0.920 & 15,840 & 166,667 & 14.57 & 10.52 \\
\hline
\end{tabular}

In the packaging, strapping, and palletizing of new containers prior to their storage for shipment, the pallets are reused and the amount of low-density polyethylene film per unit of PPB used is less than $1 \%$ by weight of the raw material. Therefore, pallets and low-density polyethylene film were excluded from the study. The environmental impacts of the operations carried out in the entrance warehouse of the fruit and vegetable products (such as screening, treatments, cleaning, packaging, etc.) were not considered. The packaging process is presented in Figure $4 \mathrm{~b}$.

The boxes, once loaded with the fruit and vegetable products in the packaging centers, are transported in refrigerated trucks of $40 \mathrm{t}$. There are 33 pallets and four boxes per row in each truck (Table 8). It should be noted that at this stage only the impact of transporting the boxes from the country of origin to the country of destination was considered. Therefore, the impact of the transport of the fruit and vegetable products was not considered in the limits of this life cycle. The total load transported by trucks was considered for the selection of the most suitable truck. The load of the boxes to be transported allowed for the estimation of the $\mathrm{tkm}$ (tons per kilometer). When assessing the fuel consumption, only the load of the boxes to be transported was considered (weight of each box multiplied by the number of boxes to be transported).

The boxes, once used in the points of sale of the countries of destination, are collected and transported back to Spain to the companies that sell fruit and vegetable products. In that process the boxes return dirty and folded. An average of $100 \mathrm{~km}$ was estimated to cover the following distances:

- Route from the points of sale or their corresponding logistics centers to the storage centers in the countries of destination; and

- Route from the sanitation center (which was located in Spain, near the fruit and vegetable marketing companies) to the packaging centers. 
Table 9 shows the information regarding the number of trucks needed to transport the used folded boxes (considering the height of the folded boxes from Germany to Spain $(2500 \mathrm{~km})$ in $40 \mathrm{t}$ non-refrigerated trucks.

The sanitation stage includes the necessary activities to allow the box to be in perfect working condition again. The dirty PPB collected are stored and kept in the proper conditions for subsequent sanitation. As in the manufacturing stage of the containers, the use of transport with forklifts was assumed to take place inside the sanitation center where dirty boxes are cleaned. The routes taken into consideration were from the truck to the entrance warehouse, from this warehouse to the washing line, from the washing line to the shipping warehouse, and from the shipping warehouse to the vehicle that distributes the clean boxes back to the packaging companies (see Figure 4).

The PPB are cleaned in automated washing tunnels where the boxes are subjected to different treatments: prewash, blow, wash and disinfection, and rinse. The water is reused in a closed circuit several times and is changed at the end of the work shift. The consumption per day is $900 \mathrm{~L}$. In addition, 9000 containers are sanitized in the wash tunnels for each $8 \mathrm{~h}$ shift, consuming $288 \mathrm{kWh}$ of low-voltage electric power per work shift and cleaning products (biodegradable detergents with 1-2\% concentration, sodium carbonate at $5 \%$ concentration, bactericidal agents, etc.) all suitable for use in food packaging. The data related to this stage were obtained from data supplied by companies that manufacture machinery and equipment for the sanitation sector $[46,47]$. Table 10 shows the total number of entries in the washing process per box.

Table 10. Information on the inputs to the washing process of a PP.

\begin{tabular}{cccc}
\hline & Entries & Quantity \\
\hline & Water & & $0.6075 \mathrm{~kg} / \mathrm{box}$ \\
\hline \multirow{2}{*}{ Detergents } & & Biodegradables & $0.0109 \mathrm{~kg} / \mathrm{box}$ \\
\cline { 3 - 4 } & & Sodium carbonate & $0.00025 \mathrm{~kg} / \mathrm{box}$ \\
\hline & Energy & & $0.03204 \mathrm{kWh} / \mathrm{box}$ \\
\hline
\end{tabular}

Once sanitized, the PPB are packed, strapped, and palletized for transport. In the activities of packaging, strapping, and palletizing sanitized containers prior to their storage for shipment, the pallets are reused. The amount of low-density polyethylene film per unit of PPB used is less than $1 \%$ by weight of the raw material. Therefore, pallets and low-density polyethylene film were excluded from the study.

The end-of-life stage consists of two processes: the transport of the boxes after their useful life to the waste treatment centers and the waste treatment processes (see Figure $4 \mathrm{~d}, \mathrm{e}$ ). The boxes when broken or no longer suitable for use, as well as the polypropylene that is lost in the injection process, are transported to the treatment centers in $16 \mathrm{t}$ trucks located at an average distance of $50 \mathrm{~km}$.

It was assumed that all the boxes necessary for the transport of fruit and vegetable products are managed in the country where sanitation and storage is carried out (since that is where quality control is also carried out); the waste is generated in Spain. Of the percentage of boxes that are broken or lost it was considered that $50 \%$ of said losses/breaks occur in the country of origin and the other $50 \%$ occurs in the country of destination (Germany) since in both sites opening and closing the boxes happens (at packaging centers, points of sale, and sanitation and storage centers) that can lead to breakage of the boxes or the identification of aesthetical damages that do not allow for their use as display-ready boxes. Depending on the number of cycles, the percentage of losses/breaks/damages, and the type of product to be transported, the amount of PPB to be managed is different (Table 11). 
Table 11. Information of the PPB to be managed at the end of life according to the number of rotations and losses/breaks/damages to be managed at the end of life.

\begin{tabular}{ccc}
\hline $\begin{array}{c}\text { Boxes to Transport 1000 } \mathbf{t} \text { (Without } \\
\text { Considering Cycles or Losses/Breaks) }\end{array}$ & $\begin{array}{c}\text { Number of Cycles } \\
\text { Considered per Box }\end{array}$ & $\begin{array}{c}\text { Boxes to Transport 1000 } \mathbf{t} \\
\text { (Considering Cycles) }\end{array}$ \\
\hline \multirow{2}{*}{166,667} & 100 & 1667 \\
\cline { 2 - 3 } & 50 & 3334 \\
\hline
\end{tabular}

The data related to the waste management treatments of plastic packaging at its end of life were extracted from EUROSTAT (European Statistics Office) database [53] (Table 12). This data refers to the wastes treated without considering the fraction of waste taken to landfills with no treatment since both types of boxes end their life in markets or logistics centers where there is strict regulation regarding the proper management of waste without a landfill.

Table 12. Percentage distribution of treatments applied to plastic packaging waste by country [53].

\begin{tabular}{ccc}
\hline Country & Germany & Spain \\
\hline Incineration/energy recovery (R1) ${ }^{*}$ & $55.61 \%$ & $0.00 \%$ \\
Recovery other than energy recovery & $0.00 \%$ & $0.00 \%$ \\
Material recycling & $0.35 \%$ & $30.53 \%$ \\
Incineration with energy recovery in waste incinerators & $40.71 \%$ & $69.47 \%$ \\
Other forms of recycling (including composting) & $3.33 \%$ & $0.00 \%$ \\
Total & $100.00 \%$ & $100.00 \%$ \\
\hline
\end{tabular}

* Using incineration facilities complying with the energy efficiency criteria set in annex II to the Waste Framework Directive for recovery operation R1 [55].

\subsubsection{Inventory Analysis for $\mathrm{CCB}$}

The unit processes of this inventory are presented, detailing entries and exits, in Figure 5. Like the PPB, the cycle of the CCB begins with the manufacture of raw materials, including Kraftliner, Semi-chemical Fluting, Testliner, and Wellenstoff. As described in previous studies [17], the paper reels are transported to the industry responsible for manufacturing the cardboard sheets and boxes. The transport of Kraftliner paper reels with $0 \%$ and $20 \%$ recycled fiber is done first by the sea in transoceanic vessels (a distance of $6000 \mathrm{~km}$ ) and then by road in $40 \mathrm{t}$ trucks (a distance of $350 \mathrm{~km}$ ). The transport of the Testliner and Wellenstoff paper reels with 100\% recycled fiber is done by road in $40 \mathrm{t}$ trucks (a distance of $220 \mathrm{~km}$ ) (Figure 3). Maritime transport was modeled with the emission factors extracted from the third report of GHG of the International Maritime Organization [48].

CCB is a multilayer box. The composition of the box changes depending on the size, as the resistance varies. For the CCB-600 box it is:

- External layer: Testliner, $100 \%$ recycled fiber, weight: $195 \mathrm{~g} / \mathrm{m}^{2}$;

- Corrugated exterior: Wellenstoff, $100 \%$ recycled fiber, weight: $170 \mathrm{~g} / \mathrm{m}^{2}$;

- Intermediate layer: Wellenstoff, $100 \%$ recycled fiber, weight: $170 \mathrm{~g} / \mathrm{m}^{2}$;

- Corrugated interior: Wellenstoff, $100 \%$ recycled fiber, weight: $190 \mathrm{~g} / \mathrm{m}^{2}$; and

- Internal layer: Testliner, $100 \%$ recycled fiber, weight: $250 \mathrm{~g} / \mathrm{m}^{2}$.

For the CCB-400 box it is:

- External layer: Kraftliner, $20 \%$ recycled fiber, weight: $135 \mathrm{~g} / \mathrm{m}^{2}$;

- Corrugated exterior: Wellenstoff, 100\% recycled fiber, weight: $150 \mathrm{~g} / \mathrm{m}^{2}$;

- Intermediate layer: Wellenstoff, $100 \%$ recycled fiber, weight: $170 \mathrm{~g} / \mathrm{m}^{2}$;

- Corrugated interior: Wellenstoff, $100 \%$ recycled fiber, weight: $170 \mathrm{~g} / \mathrm{m}^{2}$; and

- Internal layer: Kraftliner, $20 \%$ recycled fiber, weight: $170 \mathrm{~g} / \mathrm{m}^{2}$. 

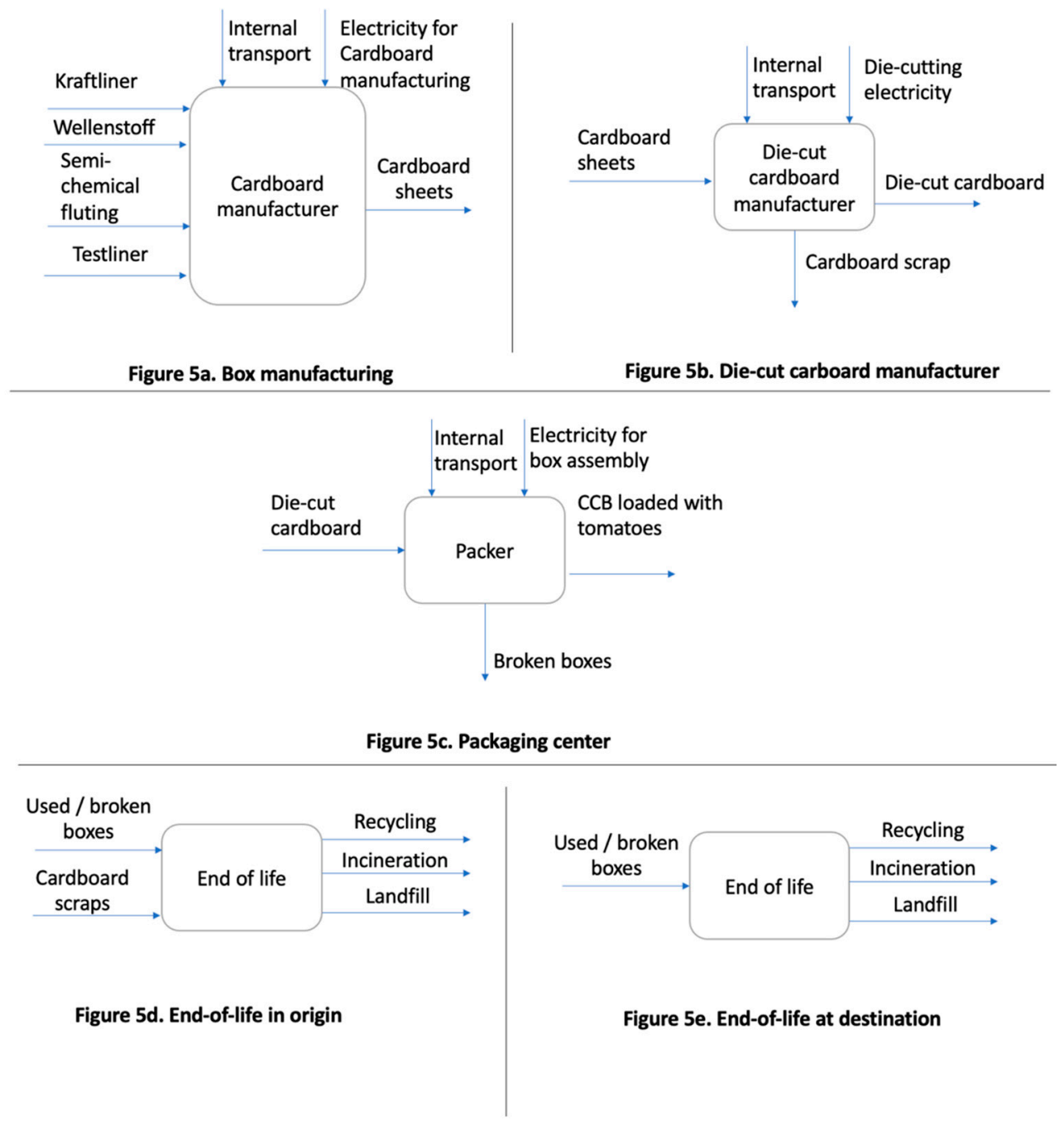

Figure 5. Unit processes for CCB (based on [17]). 5a. Box Manufacturing, 5b. Die-cut cardboard manufacturer, 5c. Packaging center, 5d. End-of-life at origin, 5e. End-of-life at destination.

In the manufacturing process of corrugated cardboard sheets, based on the information obtained by the manufacturers, a loss percentage of $10 \%$ due to the cuts in the sheet was considered. The energy consumption data of the manufacturing and die-cutting process were obtained from both European Corrugated Packaging Association (FEFCO) (2015) [42] and manufacturers of die-cutting machines such as MAIKWA [44]. The impact of the infrastructure was not considered because it is outside the system limits. Nor were the screen-printing inks (water-based) and adhesives (starch compounds and small amounts of caustic soda, borax, and anti-wetting agents) used to join the five types of paper that make up the sheet, as they make up less than $1 \%$ (inks) and $2 \%$ (adhesives) of the total mass of raw materials of a CCB [42].

Once the sheets are die-cut, they are transported to the packaging centers. One truck transports 14,750 sheets of CCB 6 or 29,500 of CCB4. To transport the $1000 \mathrm{t}$ of product, 143,001 sheets of CCB6 or 166,834 sheets of CCB4 are required, considering an additional $0.1 \%$ for losses or breakages. This transport is carried out in non-refrigerated trucks of $40 \mathrm{t}$ over an average distance of $100 \mathrm{~km}$, considering that in each truck there are 50 pallets, 295 rows of folded boxes, and 1 box per row of CCB 6 or 2 boxes per row of CCB4. These are pallets designed specifically for this use (they do not match the dimensions of the Europalet).

When packaging, strapping, and palletizing new containers prior to their storage for shipment, the pallets are reused and the amount of low-density polyethylene film per CCB 
unit used is less than $2 \%$ by weight of the raw material. Therefore, pallets and low-density polyethylene film were excluded from the study. Likewise, the environmental impacts of the operations carried out in the warehouse of entry of fruit and vegetable products (such as screening, treatments, cleaning, packaging, etc.) were excluded. Within the warehouse, the activities related to the container (functional unit) were considered, but not those related to the processing of the tomatoes, which are outside the system limits.

For the internal transports that take place in the different industrial facilities, the weight of the cardboard sheets to be transported before die-cutting and of the cardboard sheets after die-cutting, as well as the number of boxes required to transport $1000 \mathrm{t}$, are different. The weight of each uncut sheet is $0.531 \mathrm{~kg}$ and $0.478 \mathrm{~kg}$ for the die-cut sheets of CCB6. The weight of the uncut sheet of CCB4 is $0.354 \mathrm{~kg}$ and $0.319 \mathrm{~kg}$ of the die-cut sheets.

The boxes, once loaded with the tomatoes in the packaging centers, are transported in refrigerated trucks of $40 \mathrm{t}$. Each truck has a capacity for 33 pallets and four boxes per row of CCB6 or eight boxes per row of CCB4. The rows of boxes per pallet total 22 of CCB6 or 14 of CCB4. Therefore, there are about 2904 boxes per truck that include $21.72 \mathrm{t}$ (box plus tomatoes) of CCB6, whereas CCB4 implies 3694 boxes and $23.36 \mathrm{t}$. A total of 49.19 trucks are required to transport the $1000 \mathrm{t}$ defined in the objective of the study for CCB6 and 45.09 for CCB4.

Since it is a single-use container, the sanitizing stage does not apply. According to article 5 of Royal Decree 888/1988 from 29 July, "the containers of wood, cardboard and expanded polystyrene may not be reused, as well as those that cannot be cleaned and sanitized after use" [56]. Therefore, it was considered that there are no impacts associated with this type of packaging during its use stage.

The end-of-life stage consists of two processes: the transport of the boxes once their useful life is finished to the waste treatment centers and the waste treatment processes. When the boxes break or are no longer useful and the cardboard loss of the die-cutting of the sheets are transported to the treatment centers in trucks of $16 \mathrm{t}$ located at an average distance of $50 \mathrm{~km}$. It was considered that all the boxes necessary for the transport of tomato are managed in the country of destination (Germany), and the boxes that are broken during assembly $(0.1 \%)$ are managed in the country of origin (Spain).

Data regarding waste management treatments of paper and cardboard containers at their end of life were extracted from the EUROSTAT database [53]. The percentage distribution of paper and cardboard packaging waste according to treatment for Spain and Germany is described in Table 13. As previously stated, this data was obtained, eliminating landfill as this type of waste, because of the place where their life ends, which should not be in landfills.

Table 13. Percentage distribution of treatments applied to paper and cardboard packaging waste by country [53].

\begin{tabular}{ccc}
\hline Country & Germany & Spain \\
\hline Incineration/energy recovery (R1) & $12.28 \%$ & $0.00 \%$ \\
Recovery other than energy recovery & $0.00 \%$ & $0.00 \%$ \\
Material recycling & $0.03 \%$ & $5.38 \%$ \\
Incineration with energy recovery in waste incinerators & $87.33 \%$ & $94.62 \%$ \\
Other forms of recycling (including composting) & $0.36 \%$ & $0.00 \%$ \\
Total & $100.00 \%$ & $100.00 \%$ \\
\hline
\end{tabular}

\subsection{Impact Assessment and Results Interpretation}

The evaluation of the impact of the life cycle of the boxes was carried out, as described in the methodology, using the IPCC 2007 GWP 100a method, version 1.02, which incorporates the SimaPro software. This method considers factors of characterization of the GHG proposed in the fourth report (AR4) of evaluation of the IPCC [57]. 
The results describe each of the stages of the life cycle studied: manufacturing of the box (including transport to the packaging/exporter), distribution of the product, the return of the box and sanitization (when applicable), and end of life.

The results achieved are based on the hypothesis that sanitation takes place in Spain and an incidence of between $1 \%$ and $5 \%$ of breaks (depending on the number of uses) were considered for PPB6 (Figure 6) and PPB4 (Figure 7) and a 0.1\% breakage for CCB.

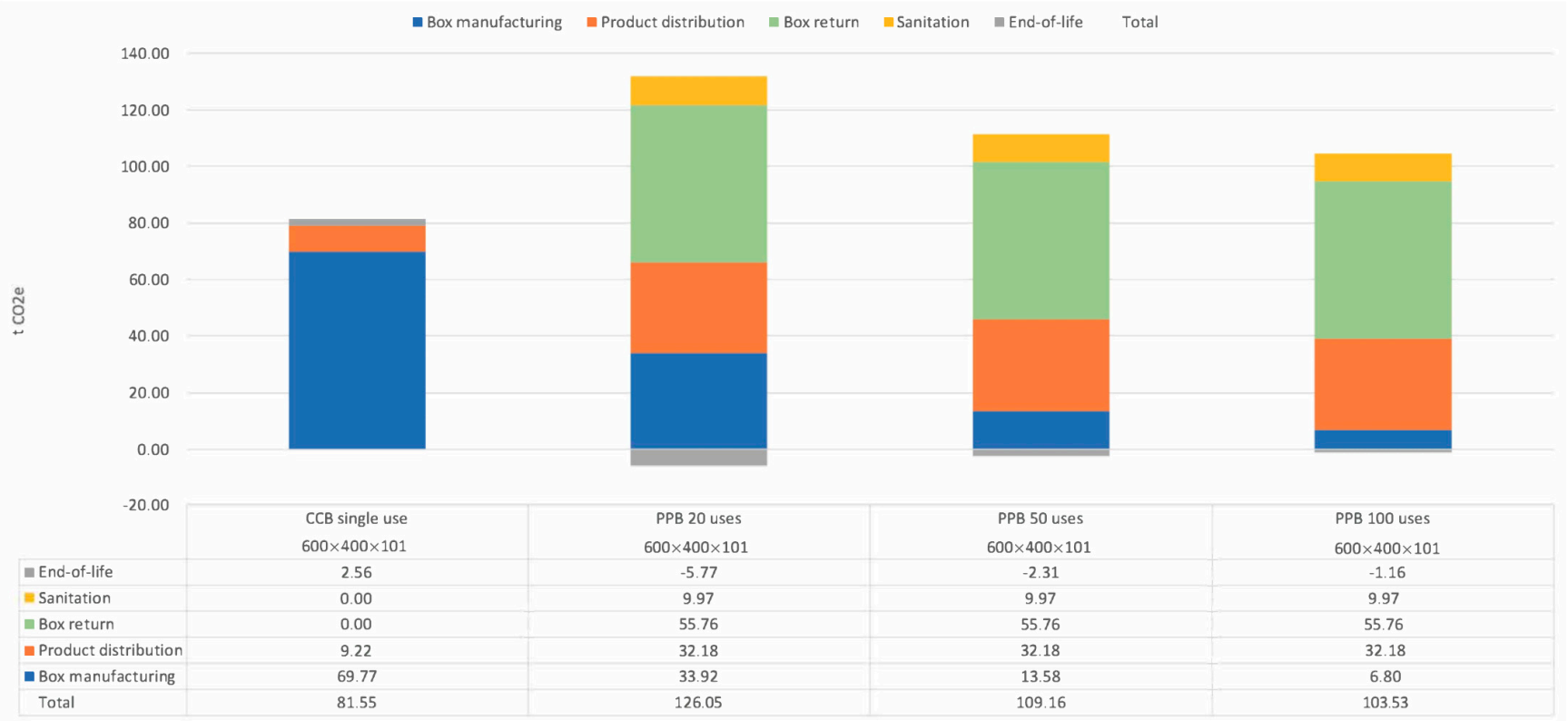

Figure 6. Sensitivity analysis: number of rotations (Table 11) using PPB6 and CCB6 (size $600 \times 400 \times 101)$.

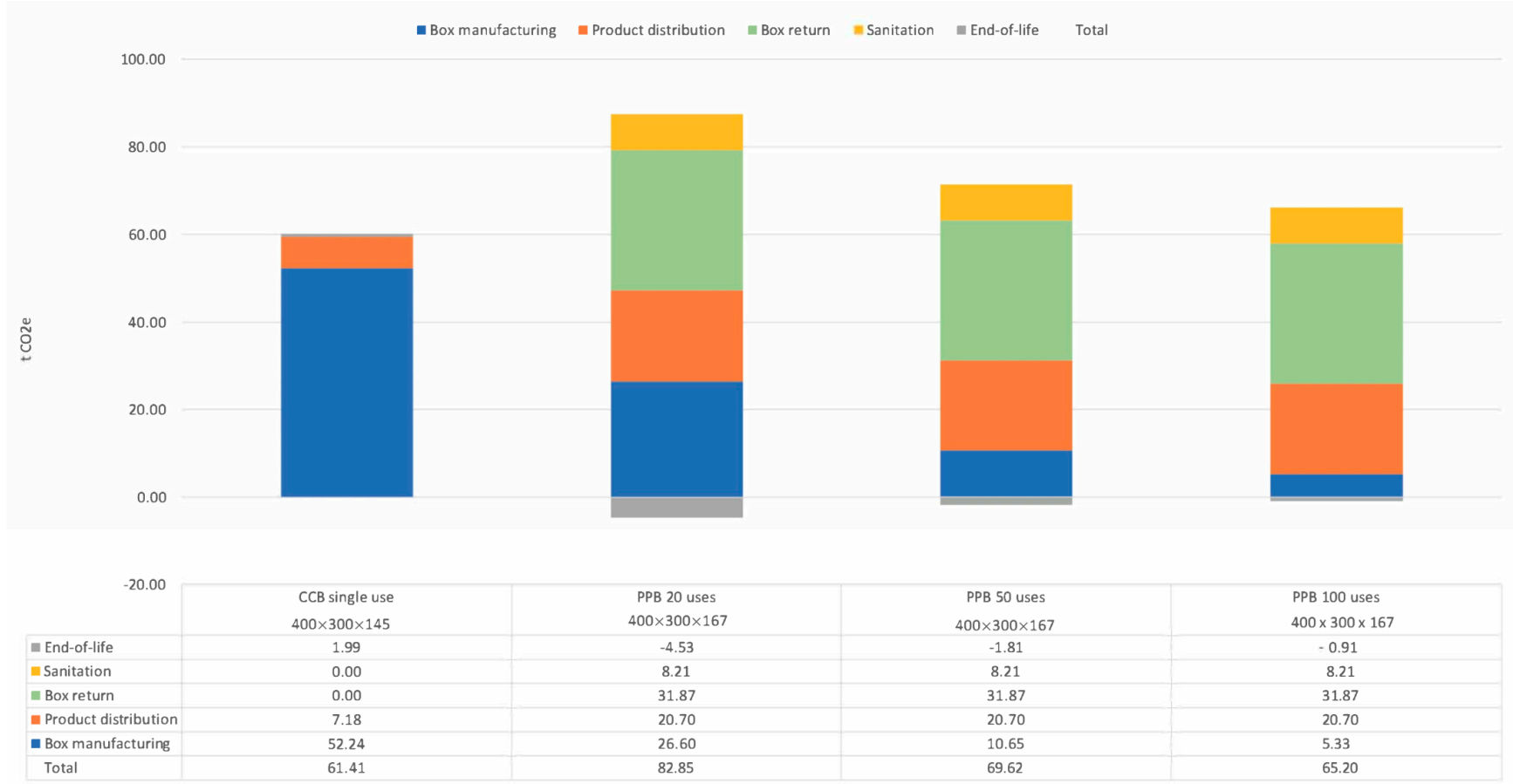

Figure 7. Sensitivity analysis: number of rotations (Table 11) using PPB4 (size $400 \times 300 \times 167)$ and CCB4 (size $400 \times 300 \times 145)$.

The stages with the most significant contribution to the CF were those related to transport: product distribution and return of the empty box in the case of PPB. The distribution stage exceeded the $20 \%$ contribution to the global CF. When it came to CCB 
where there is no sanitation stage or empty box return, the manufacturing stage took on greater weight. This result is consistent since a total of 143,001 CCB are manufactured compared to $3334 \mathrm{PPB}$ when working in the main scenario considering 50 uses per box.

However, this increase in the manufacturing stage in the CF of the CCB ceased to be relevant when comparing the entire life cycle, as the results for the main scenario with 50 uses had a CF of $31 \%$ higher than CCB. This difference increased up to $41 \%$ when the cycles of the boxes were reduced to 20 uses due to the increase of the units to be manufactured, the sanitization, and the return transport that this implies. The difference could be reduced up to $27 \%$ when the number of PPB cycles was doubled to 100 , with a clear advantage of CCB persisting.

It should be noted that variations were observed depending on the scenario of waste treatment of plastic containers in each country, with Spain being the country with the highest percentage of plastic recycling (according to EUROSTAT data). In relation to the use of the boxes, when the PPB is used only 20 times, there is a large number of boxes that go to landfill in Spain, since $83 \%$ of the boxes are removed after inspection in the sanitization centers in Spain. As the recycling of a PPB provides an important environmental benefit $\left(-1.54 \mathrm{~kg}\right.$ of $\left.\mathrm{CO}_{2} \mathrm{e} / \mathrm{kg} \mathrm{PP}\right)$, this scenario has a negative global value for the end-of-life stage.

Figures 6 and 7 shows the sensitivity analysis regarding the number of rotations. Doubling the number of uses from 50 to 100 implied a reduction of between $5 \%$ and $7 \%$ of the emissions, depending on the size of the box, but still more than CCB. There were significant differences between box sizes both in manufacturing and returning (only for $\mathrm{PPB})$. There were also differences in the product distribution stage. Comparing the same size, using CCB always has less impact than PPB.

The global impact of the PPB4 and CCB4 is less than PPB6 and CCB6. The reason for using one type of box or another depends on the size of the tomatoes and their maturity, so each type of box is used depending on the variety of tomato to be transported.

Once the product has been unloaded, the boxes are folded and sent back to their point of origin for a new load (box return). It is at the loading point where they are sanitized.

\section{Discussion and Conclusions}

The selection of the most suitable container for international road transport of fruits and vegetables is more complicated than it appears at first sight. On the one hand, it has a high economic impact. The container and packaging market for the transport of agricultural products in Spain represents EUR 1.15 billion only in products made of corrugated cardboard [58], and the five main reusable box pooling systems in Spain annually make 550 million uses of them [15]. Therefore, there is a niche market in dispute, with strong economic interests of companies struggling to increase their market share.

On the other hand, multiple factors influence container selection, starting with the different cost of acquiring a single-use cardboard box against the cost of renting the folding plastic box and the deposit needed to cover the risk of loss or breakage thereof. In the boxes analyzed in this investigation, Spanish exporting companies have to choose between paying EUR 0.40 per box compared to EUR 0.60 per one use of plastic boxes, which means between $5 \%$ and $8 \%$ of the marketing price of transported tomatoes. There is also a scientific debate about which box allows a longer shelf life or greater hygiene of the products, which results in lower product losses, whereby companies increase the possibility of reaching more distant markets and consumers receive a fresher or better-preserved product [59].

Plastic boxes require sanitation, by law, to avoid the contamination of products by dirt or leftovers of products previously transported. CCB, by being single use, practically eliminates the risk of contamination of the product that would only occur in case of negligence. Another aspect is that the folding boxes have a higher resistance to impacts and when using boxes from a single pool (supplier), they allow more homogeneous palletizing by the carriers, thus presenting certain advantages for customer logistics. Moreover, the use of a reusable, standardized plastic box, of a single color, identical to all others, without any brand or logo or indication of geographical origin, converts the merchandise 
in the box into a commodity. In this scenario, the producer loses the loyalty of the final consumer. Therefore, the exporting company can be forced to compete by price or to have to spend more money investing in other strategies such as the adhesive labelling of individual products inside the box. Notice that it is forbidden to label the reusable box to preserve its integrity and be able to carry different products in its next cycle. As a result, the same box cannot cover the need for marketing of fruit and vegetable exporting companies and commercial distribution companies' interests in the supermarket line. It should be considered that this article only analyzes an environmental aspect, comparing the $\mathrm{CF}$ of both types of boxes, which are used by cardboard export companies [60]. The composition data was provided by the distributors (pools) of folding plastic boxes made of polypropylene. The Spanish Corrugated Cardboard Manufacturers Association (AFCO) provided the cardboard box data belonging to the UNIQ Agricultural Quality Seal [61].

This study analyzes the CF of transporting $1000 \mathrm{t}$ of tomatoes from their origin, in Almería (Spain) to their main European market, Germany. The methodology called CF was used, as established in Section 7 (HCP Study Report) of the ISO 14067:2018 standard, and underwent a critical review by a panel of stakeholders according to ISO 14044:2006 and ISO/TS 14071:2014 to conduct a comparison between two alternative product systems. This comparison of the product $\mathrm{CF}$ is admissible when complying with Annex B of the ISO 14067:2018 standard (the function of the product and the omitted processes of the product system must be identical and/or not relevant for all the products compared). For the different scenarios, the CF was determined according to the IPCC 2007 GWP 100a method. As previously exposed, it should not be forgotten that some environmental aspects are not considered by CF assessments [62-64].

When the results obtained in Section 3.3 are compared, they may be surprising at first read (Figure 8). Intuitively, it is observed that the reuse of between 20 and 50 times of a folding plastic box will minimize the fact of having a manufacturing-stage $\mathrm{CF}$ much higher than that of a cardboard box. On the other hand, it could also be thought that the impact of boxes on the transport of loaded trucks should be very similar. When the results are analyzed in more detail, the causes that justify such different results appear. Suppose that instead of carrying out the study considering the necessary boxes to transport $1000 \mathrm{t}$ of tomato, the impact of an individual box is considered. In that case, the order of magnitude of the impact is easier to interpret.

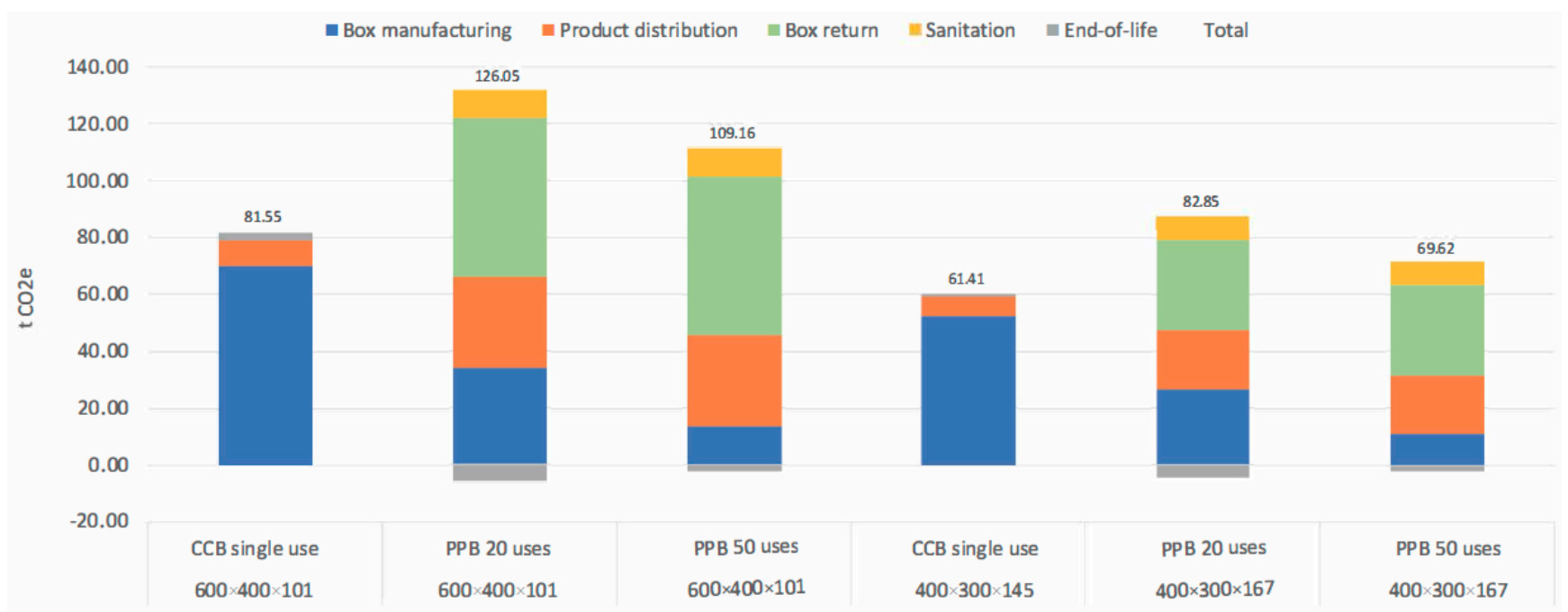

Figure 8. Results of the CF of the transport of 1000 tons of tomatoes from Almería (Spain) to the German market.

In the case of CCB6, each of the 142,858 boxes (Table 3) necessary to store and transport the $1000 \mathrm{t}$ of tomatoes requires $488.39 \mathrm{gCO}_{2} \mathrm{e}$ for their manufacture (including losses due to cuttings and defective boxes and discounting the credit obtained for fiber recycling of used 
cardboard), the product distribution stage of each box represents $64.54 \mathrm{gCO}_{2} \mathrm{e}$ and the end of life (waste management, transport to landfill, recycling, and incineration according to respective scenarios) $17.92 \mathrm{gCO}_{2} \mathrm{e}$. That is to say, the complete life cycle of a CCB6 box will cause a $570.85 \mathrm{gCO}_{2} \mathrm{e}$.

In the case of the reusable polypropylene box, assuming the intensive use scenario of 50 uses (without reaching the unlikely scenario of 100 uses, as discussed in Section 3.1.2), the store and transport of the $1000 \mathrm{t}$ of tomatoes demands the use of 166,667 boxes $(16.67 \%$ more than CCB6, since these have a real capacity of $6 \mathrm{~kg}$ instead of $7 \mathrm{~kg}$ ). If each box is used 50 times, 3333.3 boxes must be manufactured, and the manufacture of each box it will require $4073 \mathrm{gCO}_{2} \mathrm{e}\left(81.48 \mathrm{gCO}_{2} \mathrm{e}\right.$ per each of its 50 uses).

The product distribution stage of each box will imply $193.08 \mathrm{gCO}_{2}$ e since the plastic boxes have a greater height and require a greater number of trucks. Whereas plastic boxes require 63.13 trucks (Table 8) loaded with 18.93 t (tomatoes plus boxes), cardboard boxes only require 49.19 trucks (Section 3.2.2) with a load of $21.72 \mathrm{t}$ (tomatoes plus boxes).

However, the stage with the greatest impact for the CCB6 is the empty box return of the trucks, in which the impact of the truck's fuel consumption must be fully attributed to the folded empty boxes, whereas before they were prorated between the weight of the tomato and boxes. Therefore, the 21.04 trucks with $9.27 \mathrm{t}$ of empty boxes cause $334.56 \mathrm{gCO}_{2} \mathrm{e}$ per use of the CCB6 box.

The cleaning and sanitation of each box filled represent $59.82 \mathrm{gCO}_{2} \mathrm{e}$ per box. The end of life (it was assumed that $50 \%$ of the boxes are processed in Germany and the other $50 \%$ in Spain) with its different percentages for each country of recycling, landfill, and incineration, involves a recovery (reduction of emissions) of $693.00 \mathrm{gCO}_{2} \mathrm{e}$ per box $\left(13.86 \mathrm{gCO}_{2} \mathrm{e}\right.$ per each of its 50 uses).

When considering different scenarios (number of uses or rotations), the results show that a greater number of uses is required to manufacture fewer boxes, reducing the impact of the manufacturing stage, whereas using fewer boxes means less credit at the end-oflife stage. In other words, the scenarios with greater credit for recycling or incineration polypropylene also have a greater impact due to the manufacture of a greater number of boxes. Therefore, the impact of the complete life cycle of a PPB6 box (50 uses) is $655.08 \mathrm{gCO}_{2} \mathrm{e}$, whereas that of a CCB6 box is $570.85 \mathrm{gCO}_{2} \mathrm{e}$. In addition, it should be noted that as these boxes transport $7 \mathrm{~kg}$ of tomatoes instead of $6 \mathrm{~kg}, 142,847$ CCB6 boxes are needed instead of the use of 166,667 PPB6 boxes.

In the case of CCB4 and PPB4 boxes, since they both carry $6 \mathrm{~kg}$, the difference is less. In both cases, it is required to transport 166,667 boxes (functional unit $1000 \mathrm{t}$ of tomatoes), and whereas each CCB4 box represents $360.05 \mathrm{gCO}_{2} \mathrm{e}, \mathrm{PPB} 4$ boxes (50 uses) represent $428.58 \mathrm{gCO}_{2} \mathrm{e}$, with the empty return of the folded boxes responsible for $191.22 \mathrm{gCO}_{2} \mathrm{e}$.

The number of uses of the box is a fundamental variable. However, it only affects the manufacturing and end-of-life stages of the PPB boxes, since the impacts of transporting the box full of tomatoes, the return of the empty box folded, and the cleaning and sanitation of the box are independent of the number of uses. The quantity of boxes is independent of whether it is carried out by a new box or a box that has already been used on previous occasions. When considering a different number of uses or rotations affects the impact of the end-of-life stage, a compensatory effect is obtained. A greater number of uses requires manufacturing fewer boxes and reducing the impact of the manufacturing stage, whereas using fewer boxes means less credit in the end-of-life stage.

Finally, it can be deduced that a critical parameter in evaluating the impact of the boxes used to store and transport the product is the distance. The further away the destination market is, the greater the distance the trucks full of product and the trucks carrying the empty boxes will travel. Therefore, distance reduces the interest in reusable packaging. It would be interesting to consider, in a future extension of the present study, other scenarios such as different products within those that have a greater market share in exports from Almería. 
Author Contributions: Conceptualization, S.F.C.-R. and M.J.B.-C.; methodology, R.V.-C.; software and data curation, R.V.-C.; validation, S.F.C.-R.; formal analysis, M.J.B.-C.; writing-original draft preparation, V.G.L.-I.-F.; writing-review and editing, V.G.L.-I.-F. and S.F.C.-R.; visualization, V.G.L.I.-F.; supervision, S.F.C.-R.; project administration and funding acquisition, S.F.C.-R. All authors have read and agreed to the published version of the manuscript.

Funding: This research was funded by the Instituto de Producción Sostenible (IPS, Institute for Sustainable Production) located in Madrid (Spain).

Institutional Review Board Statement: Not applicable.

Informed Consent Statement: Not applicable.

Acknowledgments: The authors wish to thank to the UNIQ Agricultural Quality Seal of the Spanish Corrugated Cardboard Manufacturers Association (AFCO) and D. Manuel Sanchis Bosch for their support providing valuable information for this study.

Conflicts of Interest: The authors declare no conflict of interest.

\section{Appendix A}

\section{Disclosure Report.}

ISO 14067:2018 sets the requirements for quantifying and communicating the CF of products. When it is desired to make a CF study available to the public, the technical specification requires that the $\mathrm{CF}$ study of products has characteristics, and that specific information is provided in a Disclosure Report. This document responds to these requirements.

\section{Contact Information.}

This study was carried out by a group of professors and researchers from Universitat Politècnica de València and commissioned by the Institute for Sustainable Production (IPS). Please see the authors of the article for contact information.

\section{Name and Description of the Product Under Study.}

Two products were studied:

(a) Reusable and foldable polypropylene container used in the international refrigerated transport of fruit and vegetable products; and

(b) Recyclable corrugated cardboard container used in the international refrigerated transport of fruit and vegetable products.

\section{Carbon Footprint Type.}

This study carried out a full cradle-to-grave CF analysis.

\section{Product Category Rules.}

There is no intention to develop a CF label or a product CF declaration. Therefore, no product category rule was used.

\section{Data and Sources of Life Cycle Inventory.}

Section 3.2 presents and justifies the origin of the data used for this study. Data requirements are specified, and quality indicators are obtained.

\section{Limitation of Liability Clause Declaring the Relevant Restrictions of Miscellaneous} Potential Uses.

The results presented in this study respond to the hypotheses, scope, limitations, and other methodological considerations raised and justified in the study. Therefore, the results cannot be extrapolated to containers of other materials, different transported products, different transport destination countries, etc. The consideration of other product systems, other functional units, other scopes of the study, other system limits, or other end-of-life scenarios could impede the comparability of results. CF presents the limitations of covering only one impact category, and a better performance regarding climate change does not necessarily include an overall better environmental performance. 


\section{Process Map Including Processes in the System Limit.}

Figures 2 and 3 present both life cycles. Figures 4 and 5 represent the processes involved. Justification of the Exclusion of Limits of Processes in the System Limits.

System limits are defined in Section 3.1. No exclusions of processes previously defined were carried out.

Disclosure and Justification of the Methods Used to Avoid or Make an Assignment Due to Co-Products and Recycling.

Allocation methods for recycling are defined in the paper. The allocation procedure for loads transported is also defined in this section.

\section{Source and Date of the Characterization Factors Used.}

The IPCC methodology, developed by the World Meteorological Organization and the United Nations Environment Program and that supports the United Nations Framework Convention on Climate Change, was used. The values of the fourth evaluation report (2007), known as AR4, were applied, which are those that incorporate the software used, SIMAPRO.

\section{Results of Critical Review.}

The use of the results of the CF study to support comparative assertions requires a critical review since their application is likely to affect stakeholders outside the CF. As it is a comparative analysis between several products that fulfil the same function, if the public dissemination of the study is desired, the ISO 14026:2017 standard (Section 6.9) requires the performance of a critical review by a panel of stakeholders, following Section 7 of the ISO 14040:2006 and Section 6 of the ISO 14044:2006, and since it is a CF study, according to Section 8 of the ISO 14067:2018. ISO 14044:2006/Amd1:2017 extends the critical review processes and reviewer competencies according to the ISO/TS 14071:2014.

This study has been reviewed by a panel of experts, fulfilling the requirements established by the standards cited in this section.

\section{References}

1. Fischer, G.; Shah, M.; van Velthuizen, H. Climate Change and Agricultural Vulnerability; IIASA Publications Department: Vienna, Austria, 2002.

2. European Environment Agency. Agriculture and Climate Change; EEA Signals European Environment Agency: Copenhagen, Denmark, 2015.

3. Zocca, R.O.; Gaspar, P.D.; da Silva, P.D.; Nunes, J.; de Andrade, L.P. Introduction to sustainable food production. In Sustainable Food Systems from Agriculture to Industry. Improving Production and Processing; Galanakis, C., Ed.; Elsevier Academic Press: London, UK, 2018; pp. 3-46.

4. ECOBILAN. Analyse du Cycle de vie des Caisses en Bois, Carton Ondulé et Plastique Pour Pommes; Agence de l'Environnement et de la Maîtrise de l'Energie (ADÈME): Angers, France, 2000.

5. Hellström, D.; Saghir, M. Packaging and logistics interactions in retail supply chains. Packag. Technol. Sci. 2007, 20, 197-216. [CrossRef]

6. Kummu, M.; de Moel, H.; Porkka, M.; Siebert, S.; Varis, O.; Ward, P.J. Lost food wasted resources: Global food supply chain losses and their impacts on freshwater, cropland, and fertilizer use. Sci. Total Environ. 2012, 438, 477-489. [CrossRef]

7. Sauer, B.J.; Littlefield, J.; Franklin, W.E. Life Cycle Inventory of Reusable Plastic Containers and Display-Ready Corrugated Containers Used for Fresh Produce Applications; Reusable Pallet and Container Coalition, Inc.: Washington, DC, USA, 2004.

8. Capuz, S.; Aucejo, S.; Hortal, M.; Vivancos, J.L.; Navarro, P.; Gómez, T.; Viñoles, R.; Bastante, M.J.; Collado, D. A Comparative Study of the Environmental and Economic Characteristics of Corrugated Board Boxes and Reusable Plastic Crates in the Long-Distance Transport of Fruit and Vegetables (Estudio Comparativo de las Características Ambientales y Económicas de las Cajas de Cartón Ondulado y los Envases de Plástico Plegable Empleados en el Transporte a Larga Distancia de Frutas y Verduras); Instituto Tecnológico del Embalaje, Transporte y Logística (ITENE): Valencia, Spain, 2005.

9. Singh, S.P.; Chonhenchob, V.; Singh, J. Life cycle inventory and analysis of reusable plastic containers and display-ready corrugated containers used for packaging fresh fruits and vegetables. Packag. Technol. Sci. 2006, 19, 279-293. [CrossRef]

10. Barthel, L.; Albrecht, S.; Deimling, S.; Baitz, M. The Sustainability of Packaging Systems for Fruit and Vegetable Transport in Europe based on Life-Cycle-Analysis; On Behalf of Stiftung Initiative Mehrweg SIM (Foundation for Reusable Systems under German Civil Law): Stuttgart/Michendorf, Germany, 2007. 
11. Albrecht, S.; Beck, T.; Barthel, L.; Fischer, M.; Deimling, S.; Baitz, M. The Sustainability of Packaging Systems for Fruit and Vegetable Transport in Europe based on Life-Cycle-Analysis-Update 2009; On Behalf of Stiftung Initiative Mehrweg SIM (Foundation for Reusable Systems under German Civil Law): Stuttgart/Michendorf, Germany, 2009.

12. Levi, M.; Cortesi, S.; Vezzoli, C.; Salvia, G. A comparative life cycle assessment of disposable and reusable packaging for the distribution of Italian fruit and vegetables. Packag. Technol. Sci. 2011, 24, 387-400. [CrossRef]

13. Albrecht, S.; Branstetter, P.; Beck, T.; Fullana-i-Palmer, P.; Grönman, K.; Baitz, M.; Deimling, S.; Sandilands, J.; Fischer, M. An extended life cycle analysis of packaging systems for fruit and vegetable transport in Europe. Int. J. Life Cycle Assess 2013, 18, 1549-1567. [CrossRef]

14. Franklin Associates. A Division of Eastern Research Group. Comparative Life Cycle Assessment of Reusable Plastic Containers and Display and Non-Display-Ready Corrugated Containers Used for Fresh Produce Applications. Peer Reviewed Report 2016 Prepared for IFCO Corporation. Available online: https:/ / scrivito-public-cdn.s3-eu-west-1.amazonaws.com/f152d078e18222739495b38742ac2 b85/a05acb93a2d038b7 / f8b60f8f41a4/IFCO-RPC-Life-Cycle-Assessment-March-2016---Executive-Summary.pdf (accessed on 17 May 2018).

15. Bala, A.; Fullana, P. Comparative Assessment of Different Fruit and Vegetable Supply Options in Spain through Life Cycle Assessment (LCA) (Análisis Comparado de Diferentes Opciones de Distribución de Frutas y Hortalizas en España Mediante el Análisis de Ciclo de Vida (ACV). Available online: http:/ / www.areco.org.es/pdf/Memoria_final_Estudio_ACV_ARECO.pdf (accessed on 26 June 2018).

16. Pauer, E.; Wohner, B.; Heinrich, V.; Tacker, M. Assessing the Environmental Sustainability of Food Packaging: An extended life cycle assessment including packaging-related food losses and waste and circularity assessment. Sustainability 2019, 11, 925. [CrossRef]

17. Lo-Iacono-Ferreira, V.G.; Viñoles-Cebolla, R.; Bastante-Ceca, M.J.; Capuz-Rizo, S.F. Transport of Spanish fruit and vegetables in cardboard boxes: A carbon footprint analysis. J. Clean Prod. 2020, 244, 118784. [CrossRef]

18. Flanigan, L.; Frischknecht, R.; Montalba, T. An Analysis of Life Cycle Assessment in Packaging for Food E Beverage Applications; UNEP/SETAC Life Cycle Initiative: Nairobi, Kenia, 2013.

19. Payen, S.; Basset-Mens, C.; Perret, S. LCA of local and imported tomato: An energy and water trade-off. J. Clean Prod. 2015, 87, 139-148. [CrossRef]

20. He, X.; Qiao, Y.; Liu, Y.; Dendler, L.; Yin, C.; Martin, F. Environmental impact assessment of organic and conventional tomato production in urban greenhouses of Beijing city, China. J. Clean Prod. 2016, 134, 251-258. [CrossRef]

21. Ronga, D.; Gallingani, T.; Zaccardelli, M.; Perrone, D.; Francia, E.; Milc, J.; Pecchioni, N. Carbon footprint and energetic analysis of tomato production in the organic vs the conventional cropping systems in Southern Italy. J. Clean Prod. 2019, 220, 836-845. [CrossRef]

22. Finnan, J.M.; Donnelly, A.; Burke, J.I.; Jones, M.B. The effects of elevated concentrations of carbon dioxide and ozone on potato (Solanum tuberosum L.) yield. Agric. Ecosyst. Environ. 2002, 88, 11-22. [CrossRef]

23. Prasad, B.V.G.; Chakravorty, S. Effects of climate change on vegetable cultivation-a review. Nat. Environ. Pollut. Technol. 2015, 14, 923-929.

24. Bisbis, M.B.; Gruda, N.; Blanke, M. Potential impacts of climate change on vegetable production and product quality-A review. J. Clean Prod. 2018, 170, 1602-1620. [CrossRef]

25. FEPEX, Spanish Federation of Associations of Producers and Exporters of Fruits, Vegetables, Flowers, and Live Plants. Exports by Product and by Country. Available online: http:/ /www.fepex.es/datos-del-sector/exportacion-importacion-espa nola-frutashortalizas (accessed on 24 July 2020).

26. ISO. Greenhouse Gases. Carbon Footprint of Products. Requirements and Guidelines for Quantification (ISO 14067:2018); ISO International Organization for Standardization: Geneva, Switzerland, 2018.

27. Instituto Para la Producción Sostenible. Available online: https://www.institutoproduccionsostenible.com (accessed on 24 July 2020).

28. ISO. Environmental Labels and Declarations. Principles, Requirements, and Guidelines for Communication of Footprint Information (ISO 14026:2017); ISO International Organization for Standardization: Geneva, Switzerland, 2017.

29. ISO. Environmental Management_Life Cycle Assessment-Critical Review Processes and Reviewer Competencies: Additional Requirements and Guidelines to ISO 14044:2006 (ISO/TS 14071:2014); ISO International Organization for Standardization: Geneva, Switzerland, 2014.

30. Curran, M.A.; Young, S.B. Critical review: A summary of the current state-of-practice. Int. J. Life Cycle Assess 2014, 19, 1667-1673. [CrossRef]

31. ISO. Environmental Management-Life Cycle Assessment-Requirements and Guidelines (ISO 14044:2006); ISO International Organization for Standardization: Geneva, Switzerland, 2006.

32. ISO. Environmental management-Life Cycle Assessment-Requirements and Guidelines-Amendment 1 (ISO 14044:2006/Amd 1:2017); International Organization for Standardization: Geneva, Switzerland, 2017.

33. Kyoto Protocol. Available online: https://unfccc.int/sites/default/files/resource/docs/cop3/107a01.pdf (accessed on 24 July 2020). 
34. Myhre, G.; Shindell, D.; Bréon, F.M.; Collins, W.; Fuglestvedt, J.; Huang, J.; Koch, D.; Lamarque, J.F.; Lee, D.; Mendoza, B.; et al. Anthropogenic and Natural Radiative Forcing. In Climate Change 2013: The Physical Science Basis. Contribution of Working Group I to the Fifth Assessment Report of the Intergovernmental Panel on Climate Change; Stocker, T.F., Qin, D., Plattner, G.-K., Tignor, M., Allen, S.K., Boschung, J., Nauels, A., Xia, Y., Bex, V., Midgley, P.M., Eds.; Cambridge University Press: Cambridge, UK; New York, NY, USA, 2013.

35. Wernet, G.; Bauer, C.; Steubing, B.; Reinhard, J.; Moreno-Ruiz, E.; Weidema, B. The ecoinvent database version 3 (part I): Overview and methodology. Int. J. Life Cycle Assess 2016, 21, 1218-1230. [CrossRef]

36. Regulation (EC) No 1935/2004 of the European Parliament and of the Council of 27 October 2004 on Materials and Articles Intended to Come into Contact with Food and Repealing Directive 80/590/EEC and 89/109/EEC. Available online: https: / / eur-lex.europa.eu/legal-content/EN/ALL/?uri=CELEX:32004R1935 (accessed on 11 January 2021).

37. Spanish Ministry of the Presidency. Royal Decree 847/2011 stablishing the positive list of substances that may be employed in the manufacturing of polymeric materials intended to come into contact with food. Off. State Gaz. Gov. Spain 2011, 164, 76316-76330. Available online: https://www.boe.es/eli/es/rd/2011/06/17/847 (accessed on 11 January 2021).

38. European Printing Ink Association. EuPIA Guideline on Printing Inks Applied to Food Contact Materials. Available online: https:/ / www.eupia.org/fileadmin/Documents/Food_contact_material/2020-12-22_EuPIA_Guideline_on_Printing_Inks_ applied_to_Food_Contact_Materials.pdf (accessed on 12 January 2021).

39. European Commission. International Reference Life Cycle Data System (ILCD) Handbook-General Guide for Life Cycle AssessmentDetailed Guidance; European Commission- Joint Research Centre-Institute for Environment and Sustainability, Publications Office of the European Union: Brussels, Belgium, 2010.

40. IFCO Systems. Available online: https://www.ifco.com/ (accessed on 24 July 2020).

41. PlasticsEurope. "Plastics-the Facts 2017. An analysis of European plastics production, demand and waste data". Plastic Europe. Available online: https://www.plasticseurope.org/application/files/5715/1717/4180/Plastics_the_facts_2017_FINAL_for_ website_one_page.pdf (accessed on 24 July 2020).

42. FEFCO. European Database for Corrugated Board Life Cycle Studies. FEFCO Corrugated Packaging. 2015. Available online: http:/ / www.fefco.org/lca (accessed on 29 May 2018).

43. International Energy Agency (IEA), Energy Policies of IEA Countries-Spain. 2015 Review. Available online: https://www.iea. org/countries/spain (accessed on 24 July 2020).

44. MAIKWA Manufacturers of Machines for Cardboard Production. Available online: http:/ / carton-machines.es / 6-die-cuttingstripping-machine.html (accessed on 24 July 2020).

45. Schiffers, R.; Albert, A. The Carbon Footprint of an injection molding machine. Kunstst. Int. 2015, 6-7, 47-50.

46. DINOX, Washing Solutions. Available online: http:/ / www.dinox.es/es / (accessed on 24 July 2020).

47. MAINPE, Industrial Machinery. Available online: http:/ / www.mainpe.com (accessed on 24 July 2020).

48. IMO. Third IMO Greenhouse Gas Study 2014; International Maritime Organization: London, UK, 2015.

49. EMEP/EEA. Air Pollutant Emission Inventory Guidebook 2013 Update Sept 2014. Available online: https://www.eea.europa. eu/themes/air/air-pollution-sources-1/emep-eea-air-pollutant-emission-inventory-guidebook (accessed on 24 July 2020).

50. INSEE. Recensement de Population. Population des Communes Les Plus Peuplées. Available online: https://www.insee.fr/fr/ information/2008354 (accessed on 24 July 2020).

51. Federal Statistical Office. Statistical Yearbook, Germany, 2012; Federal Statistical Office: Wiesbaden, Germany, 2013.

52. Lange, V.; Pelka, M. Determination of Spoilage Levels of Fresh Fruit and Vegetables According to the Type of Packaging; Fraunhofer Institut für Materialfluss und Logistik: Dortmund, Germany, 2013.

53. EUROSTAT, European Statistics Office. Packaging Waste by Waste Operations and Waste Flow. Available online: https: / / appsso.eurostat.ec.europa.eu/nui/show.do?dataset=env_waspac\&lang=en (accessed on 24 July 2020).

54. Clark, D.I. Food Packaging and Sustainability: A Manufacturer's View. In Reference Module in Food Science; Elsevier: Amsterdam, The Netherlands, 2018. [CrossRef]

55. European Parliament. Directive 2008/98/EC of the European Parliament and of the Council of 19 November 2008 on Waste and Repealing Certain Directives. Available online: https://eur-lex.europa.eu/legal-content/EN/TXT/PDF/?uri=CELEX: 32008L0098\&from=EN (accessed on 24 July 2020).

56. Spanish Ministry of the Presidency Royal Decree 888/1988 for the approval of general standard about recipients containing fresh food products, perishable in nature, non-packaged or unwrapped. Off. State Gaz. Gov. Spain 1988, 187, $24293-24294$.

57. Forster, P.; Ramaswamy, V.; Artaxo, P.; Berntsen, T.; Betts, R.; Fahey, D.W.; Haywood, J.; Lean, J.; Lowe, D.C.; Myhre, G.; et al. Changes in Atmospheric Constituents and in Radiative Forcing. In Climate Change 2007: The Physical Science Basis. Contribution of Working Group I to the Fourth Assessment Report of the Intergovernmental Panel on Climate Change; Solomon, S., Qin, D., Manning, M., Chen, Z., Marquis, M., Averyt, K.B., Tignor, M., Miller, H.L., Eds.; Cambridge University Press: Cambridge, UK; New York, NY, USA, 2007.

58. AAD Market. Sectoral Report. Packing and Packaging in Spain (Informe Sectorial. Envase y Embalaje en España); Hispack: Madrid, Spain, 2018.

59. Gustavsson, J.; Cederberg, C.; Sonesson, U.; van Otterkijk, R.; Meybeck, A. Global food losses, and food waste. In Proceedings of International Congress Save Food, Düsseldorf, Germany, 16-17 May 2011; Food and Agriculture Organization of the United Nations: Rome, Italy, 2011. 
60. COEXPHAL. El envase puede mejorar la competitividad y sostenibilidad del sector hortofrutícola. Almería en Verde. La Rev. Del Agricultor 2016, 141, 6-8.

61. AFCO. Available online: https:/ / www.afco.es/sello-de-calidad-agricola-uniq (accessed on 24 July 2020).

62. Laurent, A.; Olsen, S.I.; Hauschild, M.Z. Limitations of Carbon Footprint as Indicator of Environmental Sustainability. Environ. Sci. Technol. 2012, 46, 4100-4108. [CrossRef] [PubMed]

63. Hottle, T.; Bilec, M.; Landis, A. Sustainability assessments of bio-based polymers. Polym. Degrad. Stab. 2013, 98, 1898-1907. [CrossRef]

64. Ögmundarson, Ó.; Herrgård, M.J.; Forster, J.; Hauschild, M.Z.; Fantke, P. Addressing environmental sustainability of biochemicals. Nat. Sustain. 2020, 3, 167-174. [CrossRef] 